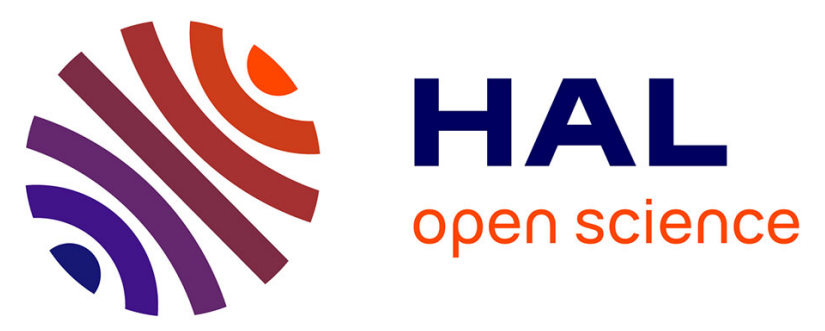

\title{
Molecular and biochemical characterization of mannitol-1-phosphate dehydrogenase from the model brown alga Ectocarpus sp.
}

Patricia Bonin, Agnès Groisillier, Alice Raimbault, Anaïs Guibert, Catherine Boyen, Thierry Tonon

\section{To cite this version:}

Patricia Bonin, Agnès Groisillier, Alice Raimbault, Anaïs Guibert, Catherine Boyen, et al.. Molecular and biochemical characterization of mannitol-1-phosphate dehydrogenase from the model brown alga Ectocarpus sp.. Phytochemistry, 2015, 117, pp.509-520. 10.1016/j.phytochem.2015.07.015 . hal01200617

\section{HAL Id: hal-01200617 https://hal.sorbonne-universite.fr/hal-01200617}

Submitted on 16 Sep 2015

HAL is a multi-disciplinary open access archive for the deposit and dissemination of scientific research documents, whether they are published or not. The documents may come from teaching and research institutions in France or abroad, or from public or private research centers.
L'archive ouverte pluridisciplinaire HAL, est destinée au dépôt et à la diffusion de documents scientifiques de niveau recherche, publiés ou non, émanant des établissements d'enseignement et de recherche français ou étrangers, des laboratoires publics ou privés. 


\section{Molecular and biochemical characterization of mannitol-1-phosphate dehydrogenase from the model brown alga Ectocarpus sp.}

Patricia Bonin, Agnès Groisillier*, Alice Raimbault, Anaïs Guibert, Catherine Boyen, Thierry Tonon.

Sorbonne Université, UPMC Univ Paris 06, CNRS, UMR 8227, Integrative Biology of Marine Models, Station Biologique de Roscoff, CS 90074, F-29688, Roscoff cedex, France

Patricia Bonin, patricia.bonin@outlook.com Agnès Groisillier, groisill@sb-roscoff.fr Alice Raimbault, alice.raimbault@orange.fr Anais Guibert, anais.guibert02@gmail.com Catherine Boyen, boyen@sb-roscoff.fr Thierry Tonon, tonon@sb-roscoff.fr

* Corresponding author. Tel.: +33 298292330; fax: +33 298292324

Email address: groisill@sb-roscoff.fr (A. Groisillier) 


\section{Abstract}

The sugar alcohol mannitol is important in the food, pharmaceutical, medical and chemical industries. It is one of the most commonly occurring polyols in nature, with the exception of Archaea and animals. It has a range of physiological roles, including as carbon storage, compatible solute, and osmolyte. Mannitol is present in large amounts in brown algae, where its synthesis involved two steps: a mannitol-1-phosphate dehydogenase (M1PDH) catalyzes a reversible reaction between fructose-6-phosphate (F6P) and mannitol-1-phosphate (M1P) (EC1.1.1.17), and a mannitol-1-phosphatase hydrolyzes M1P to mannitol (EC3.1.3.22). Analysis of the model brown alga Ectocarpus sp. genome provided three candidate genes for M1PDH activities. We report here the sequence analysis of Ectocarpus M1PDHs (EsM1PDHs), and the biochemical characterization of the recombinant catalytic domain of EsM1PDH1 (EsM1PDH1cat). Ectocarpus M1PDHs are representatives of a new type of modular M1PDHs among the polyol-specific long-chain dehydrogenases/reductases (PSLDRs). The N-terminal domain of EsM1PDH1 was not necessary for enzymatic activity. Determination of kinetic parameters indicated that EsM1PDH1cat displayed higher catalytic efficiency for F6P reduction compared to M1P oxidation. Both activities were influenced by $\mathrm{NaCl}$ concentration and inhibited by the thioreactive compound pHMB. These observations were completed by measurement of endogenous M1PDH activity and of EsM1PDH gene expression during one diurnal cycle. No significant changes in enzyme activity were monitored between day and night, although transcription of two out of three genes was altered, suggesting different levels of regulation for this key metabolic pathway in brown algal physiology. 


\section{Keywords}

Brown algae

Ectocarpus sp.

Mannitol cycle

mannitol-1-phosphate dehydrogenase

Recombinant protein 


\section{Introduction}

Primary metabolism provides energy and compounds necessary for growth, development, reproduction, and is thus directly related to biomass production. Primary metabolites encompass nucleic acids, amino acids, fatty acids and carbohydrates. Among this latter class of compounds, mannitol, a 6-carbon non-cyclic polyol/sugar alcohol, is found naturally in a wide range of organisms, except in Archaea and animals, in which it fulfills different physiological roles. In some photosynthetic organisms, mannitol is a major primary photosynthetic product used as carbon storage and translocatory compound, an important osmolyte/compatible solute, and an antioxidant (Iwamoto and Shirawai, 2005). Mannitol has also several applications in the food, pharmaceutical, medical, and chemical industries (Saha and Racine, 2011). Currently, most commercial production is achieved by the catalytic reduction of a mixture of glucose and fructose, leading to the formation of mannitol and sorbitol, which are then separated by selective crystallization (Saha and Racine, 2011; Bhatt et al., 2013). However, because of problems associated with chemical production, coupled with an increasing demand for natural products, the microbial production of mannitol has been the subject of significant interest in recent years (Saha and Racine, 2011).

Among photosynthetic organisms able to produce mannitol, brown algae (Phaeophyceae), which belong to the stramenopile lineage, are multicellular eukaryotes whose genomic content has been shaped by serial plastid endosymbiosis and horizontal gene transfers (Cock et al., 2011; Stiller et al., 2014). Most of the brown algae are marine organisms, although a small number of species are able to thrive in freshwater environment (McCauley and Wehr, 2007). Phaeophyceae exhibit some remarkable metabolic characteristics (Prigent et al., 2014), notably in their carbohydrate metabolism 
(Michel et al., $2010 \mathrm{a}$ and b). Indeed, brown algae do not store carbon fixed through photosynthesis by producing starch, saccharose, and fructans as done by most of the land plants, but instead produce the $\beta-1,3$-glucan laminarin and mannitol. This polyol can account for up to $25 \%$ of brown algal dry matter (Reed et al., 1985) according to species and harvesting time, and its metabolism was shown to occur through the mannitol cycle which involves four reactions (Iwamoto and Shirawai, 2005): two for synthesis, mannitol-1-phosphate dehydrogenase (M1PDH, EC 1.1.1.17) and mannitol-1phosphatase (M1Pase, EC 3.1.3.22), and two for degradation, mannitol-2dehydrogenase (M2DH, EC 1.1.1.67), and hexokinase (HK, EC 2.7.1.4). Interestingly, such a cycle has been identified in the apicomplexa Eimeria tenella, a parasite of chicken (Schmatz et al., 1989; Schmatz, 1997). In addition, M1PDH and M1Pase activities have been identified in fungi (Solomon et al., 2007), while M1PDH activity is also known to occur in many Gram-positive and -negative bacteria (Novotny et al., 1984; Wisselink et al., 2002), and M1Pase in some land plants (Stoop et al., 1995) and in very few bacteria (Sand et al., 2014). All M1PDH genes characterized so far belong to a specific family of alcohol dehydrogenase, the polyol-specific long-chain dehydrogenases/reductases (PSLDRs), except the enzyme characterized from Cryptococcus neoformans (Survana et al., 2000).

Despite the importance of mannitol in brown algal physiology, information on metabolic pathways involved in its synthesis and degradation were scarce and scattered until recently. Indeed, the emergence of Ectocarpus sp. (formerly included in Ectocarpus siliculosus) (Ahmed et al., 2014) as a model organism to study the biology of brown algae, and in particular the availability of its genome (Cock et al., 2010), has paved the way to study the molecular bases of the mannitol cycle in this organism. Targeted 
metabolite profiling allowed monitoring changes of primary metabolites, including mannitol, during the diurnal cycle (Gravot et al., 2010) and under abiotic stress conditions (Dittami et al., 2011). Phylogenetic analysis of genes encoding enzymes M1PDH and M1Pase suggested that the capacity to produce mannitol has been acquired probably through horizontal gene transfer from bacteria by the ancestor of brown algae (Michel et al., 2010a), and most likely after the separation of diatoms (Dittami et al., 2011b). Subsequent studies focused on the enzymatic and physiological characterization of Ectocarpus sp. M1PDH and M1Pase activities. Three genes, ESM1PDH1, 2, and 3, were identified as potential M1PDHs in the Ectocarpus sp. genome (Michel et al., 2010a), and native EsM1PDH1 gene was expressed in Escherichia coli (Rousvoal et al., 2011). Unfortunately, no overexpresssion was observed in the bacterial host, precluding purification and biochemical characterization of recombinant proteins to study their physical and catalytic properties. However, comparison of enzymatic analysis between acellular extracts of $E$. coli transformed with a vector containing the gene EsM1PDH1 or with an empty plasmid supported the assumption that EsM1PDH1 corresponded to a M1PDH. Furthermore, two genes were suggested to code for M1Pase and named EsM1Pase1 and EsM1Pase2 (Michel et al., 2010a). Both were expressed in E. coli, but only one, EsM1Pase2, provided enough soluble proteins for purification (Groisillier et al., 2014). After biochemical analysis, this recombinant protein was proved to correspond to a phosphatase with narrow substrate specify toward M1P, and further kinetic properties were determined. In addition, a gene encoding a M2DH was recently characterized from the kelp Saccharina japonica, but the purified recombinant protein was not active (Shao et al., 2014). 
In light of a renewed interest of using macroalgae (Wei et al., 2013; van Hal et al., 2014), and in particular brown algae (Wargacki et al., 2012; Enquist-Newman et al., 2013), as biomass for producing fuels and chemicals, increasing the understanding of functioning and regulation of their primary metabolism will be valuable to manage and exploit this resource. In this framework, we describe here the successful production and purification of a truncated form of the protein coded by the gene EsM1PDH1, corresponding to the catalytic domain of this enzyme. This recombinant protein was used for biochemical characterization, allowing determining the physical and catalytic properties of a new type of M1PDH. Indeed, phylogenetic analysis indicated that algal and apicomplexa M1PDHs were members of the PSLDR family of proteins, while representing a new group of M1PDHs, distinct from those characterized in bacteria and fungi. Such observations were complemented by physiological analyses including assessment of variation of expression of the three genes coding for EsM1PDH and determination of total endogenous M1PDH activity, both during one diurnal cycle.

\section{Results}

2.1. Determination of endogenous M1PDH activity and of changes in expression of EsM1PDH genes

Endogenous M1PDH activity in the direction of mannitol synthesis (reduction of F6P) was measured at four sampling times during one diurnal cycle. It ranged between $0.05 \pm 0,01$ and $0.08 \pm 0,01 \mathrm{nkat}_{\mathrm{mg}}^{-1}$ protein, with a slight increase for the sample taken during the dark period (21 $\mathrm{h}$ after the onset of the experiment) (Fig. 1A). However, such a change was not significant $(P=0.16)$. No oxidation activity of M1P in F6P was detected. In brown algae, endogenous M1PDH activity has only been measured in 
Spatoglossum pacificum (Sp. pacificum) (Ikawa et al., 1972). After partial purification,

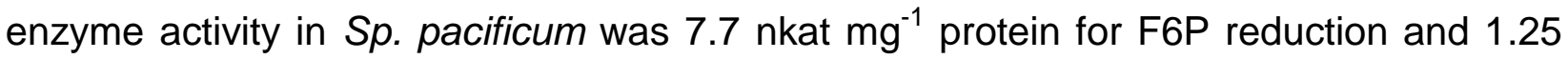
nkat $\mathrm{mg}^{-1}$ protein for M1P oxidation. Ectocarpus sp. endogenous M1PDH activity was then related to previously reported values for M1Pase activity (Groisillier et al., 2014) and for changes in the mannitol content (Gravot et al., 2010) for the same samples (Fig. 1A). Mannitol concentration was observed to increase through the light period, while this polyol is consumed during the dark phase. M1Pase activity showed a profile similar to M1PDH activity, with a limited, not significant, increase during the dark phase.

Three genes encoding M1PDHs have been identified in the Ectocarpus sp. genome, and changes in their expression were analyzed for the same samples as those considered for biochemical analyses described above. The relative expression of EsM1PDH1 increased during $12 \mathrm{~h}$ from the start of the experiment, and then decreased during the second half of the experiment, suggesting a higher expression at the daynight transition. All of these observations were statistically supported $(P<0.05)$ (Fig. 1B). The pattern observed for EsM1PDH2 was slightly different. Relative expression of this gene decreased during the first six hours, then increased up to the time $21 \mathrm{~h}$, and finally dropped down. All these variations were significant $(P<0.05)$. Profiles for both genes were similar to those previously monitored across two consecutive diurnal cycles, but with a lower resolution (every $6 \mathrm{~h}$ rather than $3 \mathrm{~h}$ in this report) (Rousvoal et al., 2011). To complete these results, changes in expression of the third gene coding for M1PDH in Ectocarpus sp., EsM1PDH3, were also analyzed. No clear pattern could be inferred, and values of relative expression for this gene were much lower than those determined for the other EsM1PDH genes. This observation was in agreement with the absence of corresponding EST for EsM1PDH3 in the Ectocarpus sp. genomic resources (Cock et 
al., 2010). However, analysis of RNA-seq data recently produced for different stages of the life cycle of this alga (Ahmed et al., 2014), and available at http://bioinformatics.psb.ugent.be/orcae/overview/Ectsi, suggested this gene to be expressed in Ectocarpus sp, but at a very low basal level.

2.2. Sequence analysis suggests that algal and apicomplexa M1PDHs represent a new type of mannitol-1-phosphate dehydrogenase

Previous sequence analysis of EsM1PDH1 and EsM1PDH2 has shown the presence of a specific $\mathrm{N}$-terminal module of unknown function when comparing with M1PDH sequences from bacteria and fungi. Interestingly, this extension was also present in the M1PDH sequence of the apicomplexa Ei. tenella. In the current study, blast searches in transcriptomic resources of brown algae provided a new sequence of M1PDH, from the kelp Saccharina japonica (S. japonica) (SjM1PDH), which contained both the N-terminal extension and the M1PDH catalytic domain. The sequence of SjM1PDH was highly identical to EsM1PDH1 (88\% of identity). Alignment of N-terminal domain from algal and apicomplexa sequences showed that this extension contained two repetitions of the motif $R-X(2)-Y-X(3)-R-X-G-X(3)-G-X(2)-G$ (X corresponding to any aa, the number of which being indicated between brackets) that was specific of brown algal and Ei. tenella sequences (Supplementary Fig. S1). Indeed, such motif was not found in any of the databases tested. So, EsM1PDH1, EsM1PDH2, EiM1PDH, and SjM1PDH contained two modules: one of unknown function in $\mathrm{N}$-terminal (named M1PDH1ext) and the dehydrogenase catalytic domain in C-terminal (named M1PDH1cat). 
To complete these observations, further analysis was focused on biochemically characterized M1PDHs identified in the BRENDA database (http://www.brendaenzymes.org), and alignment of the M1PDHcat domains from algae and Eimeria was done with sequences of M1PDHs from five bacteria and five fungi (Fig. 2). Sequences of this domain from the Gram negative bacteria Shigella flexneri (Sh. flexneri) and from the green microalgae Micromonas were added because the former protein represented the only M1PDH for which a three-dimensional structure has been obtained, and the others were shown to be very similar to Ectocarpus M1PDHs (Rousvoal et al., 2011). Identity between bacterial and algal/apicomplexa or between fungal and algal/apicomplexa sequences ranged between 17 to $23 \%$, whereas identity between bacterial and fungal M1PDHs was between 33 and $40 \%$.

After aligning these sequences, conserved features of PSLDRs defined by Klimacek et al. (2003), i.e. the three residues G7, D158 and K212 (numbering according to the result of the alignment), and the five blocks $A$ to $E$, were identified (Fig. 2). Block $A$ corresponded to the $\mathrm{NAD}(\mathrm{P})^{+}$fingerprint motif and contained the residues H-F-G-A-G-NI-G-R-G-X-I-G in bacterial M1PDHs. This motif becomes G-X-G-X-X-G-X-G when including fungal and algal/apicomplexa sequences, and contained the typical $\mathrm{NAD}^{+}$ fingerprint region G-X-G-X-X-G identified by Bellamacina (1996). The block B, which included the residue D158, was very conserved in algal/apicomplexa proteins and was flanked by two C residues. Blocks $C$ and D contained residues $E 177$ and K212, respectively. Curiously, the block E, which featured the amino acids R280, N283 and K300 well conserved in bacterial and fungal sequences, exhibited more diversity in the algal/apicomplexa sequences (Fig. 2). To better understand the real positioning of these M1PDHs among PSLDRs, a phylogenetic tree was constructed with proteins considered 
in Fig. 2, together with 33 additional proteins belonging to several PSLDR sub-families. Among these 33 sequences, 24 (23 bacterial and one fungal) were previously described in Klimacek et al. (2003), and nine identified by blastP searches (Altschul et al., 1997). PSLDR proteins grouped into three highly supported clades (Fig. 3): M1PDHs from bacteria and fungi, M1PDHs from algae and apicomplexa, and others PSLDRs known as D-mannitol 2-dehydrogenase (M2DH, EC 1.1.1.67), D-mannonate 5-oxidoreductase (MAOR, EC 1.1.1.57), D-altronate 5-oxidoreductase (ALOR, EC 1.1.1.58), Dfructuronate reductase (FUR, EC 1.1.1.57), and D-arabinitol 4-dehydrogenase (DALD, EC 1.1.1.11).

To complete this analysis, attempts were made to predict structural similarities between EsM1PDH1cat and the M1PDH from Shigella flexneri, the only M1PDH for which three-dimensional structure has been determined (PDB $3 \mathrm{H} 2 \mathrm{Z}$ ). However, the percentage of identity between the algal and bacterial sequences was too low (17\%) to make any predictions by structure homology modelling reliable.

2.3. Purification of the recombinant catalytic domain of ESM1PDH1 and its biochemical characterization

To characterize the M1PDH activity of Ectocarpus sp., several attempts were made to over-express the native gene EsM1PDH1 in E. coli (Rousvoal et al., 2011). However, no over-expression of this protein was observed, even if EsM1PDH1 F6P reduction and M1P oxidation activities were estimated to be $0.36 \mathrm{nkat} \mathrm{mg}^{-1}$ protein and 0.24 nkat $\mathrm{mg}^{-1}$ protein respectively in bacterial protein extracts.

To obtain the over-expression of EsM1PDH1, the corresponding gene was codon-optimized for expression in E. coli. Moreover, to consider the fact that EsM1PDH1 
is a protein with two distinct domains, two types of constructions were considered: a first one corresponding to the full sequence, and a second one representing the catalytic domain of this protein. Bacteria containing each construct, i.e. pEsM1PDH1full and pEsM1PDH1cat, were used for small-scale purification tests. Over-expressed recombinant proteins were obtained from both plasmids, but in different fractions: the inclusion bodies, i.e. the insoluble fraction, for pEsM1PDH1full, and the soluble fraction for pEsM1PDH1cat.

Recombinant his-tagged EsM1PDH1cat was purified by a two-step protocol based on $\mathrm{Ni}^{2+}$-affinity chromatography (Fig. 4A) and gel filtration (Fig. 4B). After each step, the presence of the EsM1PDH1cat proteins was confirmed by Western-blotting using anti-histidine tag antibodies and by measuring F6P reduction activity. SDS-PAGE results showed that the Superdex 200 column step improved the level of purification of the recombinant enzyme. The purity of the protein was confirmed by Dynamic Light Scattering (DLS) experiment. However, during gel filtration, a significant portion of the proteins was lost as inactive aggregates in the first peaks of elution (Fig. 4B). The final yield of purification after this protocol was about 5-6 mg for $500 \mathrm{ml}$ of culture in ZYP5052 medium. The apparent molecular mass of the functional his-tagged proteins eluted after size exclusion chromatography was estimated to be around $42 \mathrm{kDa}$. Comparison of this result with the theoretical mass of $43 \mathrm{kDa}$ indicated that EsM1PDH1cat is functional as a monomeric form in solution, as already determined for others characterized members of the PSLDR family (Table 1).

Specificity of EsM1PDH1cat was determined by assaying activity in presence of different potential substrates at 50 and $100 \mathrm{mM}$ final concentrations, and with $N A D(H)$ as a co-factor. Reduction of F6P, glucose-6P and mannose-6P, and oxidation of M1P, 
glucose-1P and fructose-1P tested. These experiments showed that the EsM1PDH1cat enzyme is specific for F6P and M1P. Using $\operatorname{NADP}(\mathrm{H})$ as an alternative co-factor, F6P reduction activity was about $10 \%$ of the activity measured with $\mathrm{NADH}$ and M1P oxidation activity showed less than $40 \%$ of the activity determined in presence of $\mathrm{NAD}^{+}$. In addition, EDTA at a final concentration of $2.5 \mathrm{mM}$ in the reaction mixture did not alter F6P reduction. These results indicated that EsM1PDH1cat is a reversible NADdependent M1PDH. Purified EsM1PDH1cat had a specific activity of $0.77 \mu \mathrm{kat} \mathrm{mg}^{-1}$ protein for F6P reduction with $\mathrm{NADH}$ at $\mathrm{pH}$ 7.0. For M1P oxidation at $\mathrm{pH} 9.0$, the specific activity was $0.26 \mu \mathrm{kat} \mathrm{mg}^{-1}$ protein. These activities were 3- to 15 -fold lower than those measured for characterized microbial M1PDHs listed in Table 1.

To determine optimal buffer solutions and $\mathrm{pH}$ conditions, different combinations were tested for F6P reduction and M1P oxidation. These experiments showed that Tris$\mathrm{HCl}$ was the most efficient to measure EsM1PDH1cat activity (Fig. 5A). The optimum pH for the reduction of $\mathrm{F} 6 \mathrm{P}$ was 7.0 , with $46 \%$ and $23 \%$ of residual activity at $\mathrm{pH} 8.5$ and $\mathrm{pH}$ 9.0 in presence of Tris- $\mathrm{HCl}$ buffer respectively. The activity decreased to $3 \%$ at $\mathrm{pH} 5.5$ in MES buffer, considering that, at $\mathrm{pH} 6.7$ in this buffer, the activity was only $51 \%$ of the maximum activity measured. The optimum $\mathrm{pH}$ for oxidation of M1P was 9.0 , with $75 \%$ and $35 \%$ of the maximum activity observed at $\mathrm{pH} 8.0$ and 7.5 in Tris- $\mathrm{HCl}$ buffer respectively. At pH 11 in CAPS buffer, this activity was close to zero. These values of optimum pHs were in accordance with those measured for M1PDHs isolated from diverse organisms (Table 1). The optimal temperature for $\mathrm{F} 6 \mathrm{P}$ reduction was $30^{\circ} \mathrm{C}$ in Tris- $\mathrm{HCl}$ buffer at $\mathrm{pH} 7.0$ (Fig. 5B), remained at about $35 \%$ of its maximum activity at 5 $10^{\circ} \mathrm{C}$, but was less than $5 \%$ at $50^{\circ} \mathrm{C}$. The influence of $\mathrm{NaCl}$ was tested in both reactions catalyzed by $\mathrm{M} 1 \mathrm{PDH}$. In presence of $\mathrm{F} 6 \mathrm{P}$ or M1P as substrate, the EsM1PDH1cat 
activity was higher when the reaction mixture contained $200 \mathrm{mM}$ of $\mathrm{NaCl}$, with value double when compared to those measured in absence of sodium chloride (Fig. 6). This is slightly different from previous results obtained for bacterial extracts containing EsM1PDH1: while a significant increase in the F6P reduction was observed in presence of $100-200 \mathrm{mM} \mathrm{NaCl}$, a decrease in M1P oxidation was detected when $\mathrm{NaCl}$ was added to the reaction mixture (Rousvoal et al., 2011).

Additional tests were done with different concentrations of pHMB, a thioreactive compound, and total inhibition of both reactions catalyzed by EsM1PDH1cat was observed in presence of $0.1 \mathrm{mM}$ of this compound. Similar results were obtained with $0.5 \mathrm{mM}$ of this chemical when activities were measured in E. coli extracts prepared from bacteria transformed with a plasmid containing the EsM1PDH1 gene (Rousvoal et al., 2011).

The purified EsM1PDH1cat protein exhibited a typical Michaelis-Menten kinetics when assayed with increasing concentrations of its substrates (F6P, M1P, NADH and $\mathrm{NAD}^{+}$), and apparent $K_{\mathrm{m}}$ and $V_{\mathrm{m}}$ were determined from the Lineweaver-Burk plots (Supplementary Fig. S2). The $K_{\mathrm{m}}$ values for F6P and M1P were 0.19 and $0.38 \mathrm{mM}$ respectively, and for $\mathrm{NADH}$ and $\mathrm{NAD}^{+} 0.16$ and $0.02 \mathrm{mM}$ respectively (Table 1). Although the $K_{\mathrm{m}}$ for $\mathrm{F} 6 \mathrm{P}$ and $\mathrm{M} 1 \mathrm{P}$ were in the same range, the catalytic efficiency $\left(k_{\text {cat }} / K_{\mathrm{m}}\right)$ for F6P $\left(170 \mathrm{mM}^{-1} \mathrm{~s}^{-1}\right)$ was 5 -fold higher than for M1P $\left(29 \mathrm{mM}^{-1} \mathrm{~s}^{-1}\right)$. Interestingly, analysis of kinetic data determined for other M1PDHs showed that apparent $K_{\mathrm{m}}$ values for M1P were always lower than those for F6P, except for the brown alga $S p$. pacificum for which $K_{\mathrm{m}}$ values $(0.28$ and 0.25 for F6P and M1P, respectively) were similar to those obtained for EsM1PDH1cat. The only macroalgal M1PDH purified to homogeneity so far is the native form of the mangrove red alga Caloglossa continua, 
which displayed a $K_{\mathrm{m}}$ for F6P very similar to brown alga $(0.15 \mathrm{mM})$, whereas the $K_{\mathrm{m}}$ for M1P was very similar to other M1PDHs studied (0.051 mM).

\section{Discussion}

\subsection{Evolution of a distinct group of M1PDHs in algae and apicomplexa}

There are several routes for mannitol metabolism in nature. One is the conversion of M1P to F6P by a M1PDH in E. coli (Novotny et al., 1984) and homofermentative lactic acid bacteria (LABs) such as Lactococcus lactis (Wisselink et al., 2002). A second one corresponds to the direct reduction of fructose to mannitol by a mannitol-2dehydrogenase (M2DH) in heterofermentative LABs (Wisselink et al., 2002). In addition, in a wide range of land plants, mannose-6-phosphate (Mose6P) can be converted by a Mose6P reductase and a M1Pase to mannitol in source tissues before being transported and used in sink tissues (Stoop et al., 1996). To finish, a mannitol cycle has been described in fungi, apicomplexa, and algae, and it involves four reactions: 1) the reduction of photoassimilate fructose-6-phosphate (F6P) to mannitol-1-phosphate (M1P) catalyzed by a mannitol-1-phosphate dehydrogenase (M1PDH, EC.1.1.1.17), this reaction being reversible, at least in vitro; (2) the hydrolysis of the phosphate group from M1P to produce mannitol, catalyzed by mannitol-1-phosphatase (M1Pase, EC.3.1.3.22); (3) mannitol can be converted to fructose by a mannitol-2-dehydrogenase (M2DH, EC.1.1.1.67); (4) fructose is then phosphorylated by a hexokinase (HK, EC.2.7.1.4) to re-enter into general metabolism. In this report, we focus on M1PDHs, which belong to the PSLDRs, a family of oxidoreductases (Klimacek et al., 2003). This observation is supported by the presence of PSLDRs conserved residues and specific blocks within M1PDHs. In addition, analysis of the evolutionary relationships of algal sequences with 
bacterial and fungal biochemically characterized M1PDHs and PSLDRs enzymes indicates that algal and Eimeria M1PDHs form a new branch of M1PDHs within the PSLDR family of dehydrogenases, and this branch is clearly divergent from bacterial and fungal enzymes catalyzing M1PDH activities. These latter sequences represent short chain M1PDHs, compared to their algal and apicomplexa counterparts which are long chain M1PDHs. Interestingly, other types of proteins catalyzing M1PDH activity have been demonstrated in the soil bacterium Acinetobacter (Sand et al., 2013 and 2014), and the mammal pathogen Cr. neoformans (Suvarna et al., 2000). Indeed, analysis of their sequences and comparison with M1PDHs belonging to the PSLDR family indicate that they are distinct from these latter M1PDHs: M1PDH activity in Acinetobacter is provided by a bi-functional M1PDH-M1Pase protein distinct of green microalgal modular proteins since position of both catalytic domains are inverted (Sand et al., 2014); Cr. M1PDH is a member of the zinc-containing long-chain alcohol/polyol dehydrogenase family (Suvarna et al., 2000). Based on these observations, enzyme with M1PDH activities have arisen from different sequences which are not completely unrelated because there were all dehydrogenases, and thus represent an example of convergent evolution termed repeated evolution as defined by Picherski et al. (2011).

3.2. Biochemical properties of the recombinant EsM1PDH1 catalytic domain and comparison with M1PDHs of various organisms

To better characterize M1PDH activity in brown algae, heterologous expression of EsM1PDH1full and EsM1PDH1cat was assayed in E. coli. So far, in photosynthetic organisms, only the native form of M1PDH protein from the red alga $C$. continua has been purified and characterized (Iwamoto et al., 2003). The kinetic parameters of 
recombinant EsM1PDH1cat was investigated after purification by $\mathrm{Ni}^{2+}$-affinity chromatography and gel filtration. This method allowed us to obtain a purified active enzyme, indicating that the $\mathrm{N}$-terminal extension is not necessary for M1PDH activity. This enzyme was active as a monomer, specific of M1P for oxidation and of F6P for reduction, and did not require metal ions for catalysis. These observations are consistent with those obtained for other purified M1PDHs belonging to the PSLDR family (Table 1). Conversely, M1PDH protein from Cr. neoformans belongs to medium-chain reductase (MDR) family, and is active as tetramer and on different substrates (Survana et al., 2000). All M1PDH enzymes have a high preference for using $N A D(H)$ instead of $\operatorname{NADP}(H)$, except the M1PDH of Acenitobacter sp. which prefers NADP $(H)$ (Sand et al., 2013), and the $E$. tenella enzyme which could utilize equally both $N A D P(H)$ and $N A D(H)$ (Schmatz et al., 1989).

Ectocarpus sp. is an alga living in seawater where $\mathrm{NaCl}$ concentration is normally about $450 \mathrm{mM}$ (Dittami et al., 2009), but this value can be altered according to changing environmental conditions. In this context, influence of $\mathrm{NaCl}$ concentration on different Ectocarpus enzymatic activities has been studied. Indeed, $\mathrm{NaCl}$ addition increased both activities of EsM1PDH1cat with an optimum at $200 \mathrm{mM}$, and of GDP-mannose dehydrogenase with an optimum at $500 \mathrm{mM}$ (Tenhaken et al., 2011). In contrast, a decrease of M1Pase activity by $67 \%$ was measured in presence of $400 \mathrm{mM} \mathrm{NaCl}$ (Groisillier et al., 2014). Otherwise, inhibition of M1PDH activity by pHMB supported the importance of thiol groups in the activity of EsM1PDH1cat. This observation was not specific to algal M1PDHs since SH-enzymes membership has also been demonstrated for C. continua (Iwamoto et al., 2003), Sp. pacificum (Ikawa et al., 1972), Ei. tenella (Alloco et al., 2001) and E. coli (Chase, 1986). M1PDH sequences of Enterobacteriales 
(E. coli, Sh. flexneri, and K. pneumonia) in Fig. 2 possessed a unique aa residue with a thiol group, i.e. a cysteine, at position 120 . This aa, perfectly conserved in the alignment with algal and apicomplexa sequences, could have an important role in the catalytic site of these enzymes, and thus represented an interesting candidate for targeted mutagenesis. Effects of $\mathrm{NaCl}$ and pHMB on M1PDH enzymatic activities measured in $E$. coli extracts produced from bacterial expressing the gene EsM1PDH1 and for recombinant EsM1PDH1cat were slightly different (Rousvoal et al., 2011), and these discrepancies may be explained by the physiological context in which reduction of F6P and oxidation of M1P were measured, i.e. bacterial extracts versus purified recombinant proteins.

M1PDHs of the brown algae Sp. pacificum and Ectocarpus sp. likely differed from others characterized M1PDHs primarily by lower specific activity for F6P reduction and higher $K_{\mathrm{m}}$ for M1P (Table 1). However, these observations have to be taken cautiously because enzyme activities have been measured in different organisms under various experimental conditions, and with different preparations of proteins extracts. In the same vein, it was difficult to compare M1PDH activity determined in the Ectocarpus crude extracts, which may result from three enzymes (EsM1PDH1, 2, and 3), with this calculated for the purified recombinant truncated M1PDH1. Indeed, experiments were done with protein mixtures obtained under different protocols and physiological contexts.

\subsection{Changes in the mannitol biosynthetic pathway through the diurnal cycle}

Based on the data presented in Figure 1, no correlation could be established between M1PDH/M1Pase enzymatic activities and variations in the mannitol content during the 24 h-experiment. However, significant changes were observed in transcription 
of the Ectocarpus M1PDH genes, notably the two most highly expressed EsM1PDH1 and EsM1PDH2. Their relative expression increased at the day-night transition for the former, and the night-day transition for the latter. These changes in expression did not seem to be reflected in the total M1PDH endogenous activity which remained rather constant over the 24 hours, while the quantity of mannitol decreased during the night. Such observation suggested different mechanisms of regulation occurred in Ectocarpus sp. to alter the synthesis of mannitol. In line with this assumption, there is limited information on a possible regulation at the protein level of the M1PDH activity in eukaryotes. To our knowledge, data are available only for Ei. tenella (Schmatz 1997). Indeed, EiM1PDH was shown to bind proteins identified as 14-3-3 based on aa sequence homology. It is known that these proteins have roles in signal transduction, transcription regulation and cell cycle control (Aitken, 1996; Banik et al., 1997). It was then suggested that binding of 14-3-3 homodimers to the M1PDH inhibited the production of mannitol, In this context, it would be interesting to assess if the Ectocarpus enzyme EsM1PDH1 formed complex with such regulatory proteins, in particular by interactions involving the $\mathrm{N}$-terminal module.

\section{Concluding remarks}

Mannitol is a ubiquitous metabolite, and its synthesis in brown algae, from F6P and through M1P, is a two-step process involving rather unique enzymes. Indeed, algal and apicomplexa M1PDHs represent a new type of M1PDH within the PSLDRs, and the characterization of the recombinant catalytic domain of EsM1PDH1 provides first insights on the biochemical behavior of such enzymes. These latter results complement the recent characterization of a new type of phosphatase, specific of M1P, in Ectocarpus 
(Groisillier et al., 2014). Such observations pave the way for future analysis to gain a better understanding about the physiological role, functioning and regulation of mannitol synthesis in brown algae, notably by assessing relationships between structure and function of relevant enzymes, and by altering mannitol synthesis in vivo when protocol(s) for targeted genetic modification of Ectocarpus will be available.

\section{Materials and methods}

\subsection{Preparation of algal material}

Samples used in this study corresponded to algae harvested at regular intervals $(3 \mathrm{~h})$ through one diurnal cycle. Three independent cultures were grown under a photoperiod of $10 \mathrm{~h}$ light and $14 \mathrm{~h}$ dark, and photosynthetically active radiation was provided by Philips daylight fluorescence tubes at a photon flux density of $40 \mu \mathrm{mol} \mathrm{m}$ $\sec ^{-1}$ as previously described (Gravot et al., 2010; Rousvoal et al., 2011). These samples were used to extract total RNAs and for preparation of protein extracts (Groisillier et al., 2014). For protein extractions,, algae were ground with liquid nitrogen, and one part of the resulted powder was mixed with four parts $(w / v)$ of extraction buffer (25 mM MOPS, pH 7.2, $15 \mathrm{mM}$ EGTA, $15 \mathrm{mM} \mathrm{MgCl}_{2}, 2 \mathrm{mM}$ DTT, 0.5\% polyvinylpyrrolidone, protease inhibitors). After homogenization by a Wheaton tissue grinder and incubation at $4^{\circ} \mathrm{C}$ for 30 min, extracts were sonicated six times for $10 \mathrm{sec}$ and centrifuged at $14,000 \mathrm{rpm}$ for $30 \mathrm{~min}$. Concentrations of proteins were determined using a Nanodrop ND-1000 spectrophotometer (Thermo Scientific, USA).

\subsection{Quantitative real-time $P C R$}


Extraction of total RNAs from Ectocarpus sp. and RT-qPCR were conducted as previously described (Le Bail et al., 2008). cDNAs were synthetized from $500 \mathrm{ng}$ of total RNAs using the Improm-II ${ }^{\mathrm{TM}}$ Reverse Transcription System (Promega, USA) according to the manufacturer's instructions. Quantitative PCR reactions were performed in 96-well plates (Thermo Scientific, USA) on a Light-Cycler 480 (Roche, France). Specific pairs of primers, designed in this study, were 5'-CTGGGCTGTGGCTCGCCTTTTGC-3' and 5'GTGCGTGCCGGATGATCT-3' for EsM1PDH1， 5'-ATGCCGTACCCTGCTGAGAT-3' and 5'-TGTCTTCGACCCCACTGAATC-3' for EsM1PDH2, 5'AGTGTCGAGACGGAGGAAGAG-3' and 5'-GAGAACCGGTCGAGAGTTTG-3' for EsM1PDH3, and amplicon size was $65 \mathrm{bp}, 62 \mathrm{bp}$, and $71 \mathrm{bp}$ respectively. The composition of each reaction was as follow: $1.25 \mathrm{ng}$ of $\mathrm{cDNA}, 0.5 \mu \mathrm{M}$ of each primer, 5 $\mu \mathrm{l}$ of SYBR Green $2 X$ (Roche, France) and water to a final volume of $10 \mu \mathrm{l}$. Each algal sample was performed in three technical replicates. The program was: $95^{\circ} \mathrm{C}$ for $5 \mathrm{~min}$, followed by 45 cycles at $95^{\circ} \mathrm{C}(10 \mathrm{~s}), 50^{\circ} \mathrm{C}(5 \mathrm{~s})$ and $72^{\circ} \mathrm{C}(5 \mathrm{~s})$. The expression of the gene EF1a was used to normalize the results.

\subsection{Sequence retrieval and phylogenetic analysis}

EsM1PDH1, 2 and 3 sequences were used for BlastP analysis against the UniProtKB/Swiss-Prot database to retrieve the closest biochemically characterized homologues of EsM1PDHs, and against the Protein Data Bank (PDB) to identify the most similar proteins for which three-dimensional structure has been obtained. In addition, blast searches were carried out against brown algal EST resources available for Laminaria digitata (Roeder et al., 2005), Sargassum binderi (Wong et al., 2007), Fucus vesiculosus and Fucus serratus (Pearson et al., 2010). This was completed by 
analysis of publicly available raw RNA-seq data for Saccharina japonica (Deng et al., 2012; SRA accession number SRX107054 and SRX107055), Saccharina latissima (Heinrich et al., 2012; SRA accession number SRX081375), and Macrocystis pyrifera (Konotchick et al., 2013; SRA accession numbers SRX220277, SRX220275, SRX220273, and SRX220272) that were cleaned-up through a custom made pipeline and assembled with CLC-assembly-cell. The presence of algal/apicomplexa M1PDH Nterminal module in other organisms was assessed by blastP analysis against the nonredundant protein sequences database (http://www.uniprot.org/blast/).

The M1PDHs proteins were aligned using the ClustalW algorithm (Thompson et al., 1994) integrated in the BioEdit sequence alignment editor (Hall, 1999). This initial alignment permitted to define the limits of both the $\mathrm{N}$-terminal and of the dehydrogenase domains in the algal and apicomplexa sequences. Then, these $\mathrm{N}$-terminal modules and the C-terminal sequences (i.e. the catalytic modules) were aligned separately using the MEGA v.5.05 software (Tamura et al., 2011). The program ESPript3 (Robert and Gouet, 2014) was used to highlight sequence similarities and secondary structure information. The phylogenetic tree of the algal and apicomplexa catalytic modules and of the fulllength bacterial and fungal sequences was constructed using the Maximum Likelihood method and the reliability of the internal branch was assessed using the bootstrapping method (200 bootstrap replicates) as implemented in the MEGA v.5.05 software (Tamura et al., 2011).

\subsection{Cloning of EsM1PDH1cat and purification of recombinant protein}

To optimize the expression of EsM1PDH1 (Esi0017_0062; UniProt accession number D7FMJ8), this gene was codon-optimized for expression in E. coli (GeneArt ${ }^{R}$ 
Gene Synthesis, Life Technologies, USA). Using this synthetic gene as a template, the full-length EsM1PDH1 gene was amplified with the forward primer 5'GGGGGGGGATCCATTGATATTAGCCTGGCACCGCC-3' (BamHI restriction site in italic) and the reverse primer 5'-CCCCCCGAATTCTTACGGCTGGCTAACCGGTGCGG3' (EcoRI restriction site in italic). The sequence corresponding to the catalytic domain, named EsM1PDH1cat (nucleotides 399 to 1578), was amplified with the forward primer 5'-GGGGGGGGATCCGATATTGATACACCGGTTACCAAAC-3' (BamHI restriction site in italic) and the reverse primer 5'CCCCCCGAATTCTTACGGCTGGCTAACCGGTGCGG-3' (EcoRI restriction site in italic). These two PCR fragments were cloned into the vector pFO4 (adding a six histidine tag at the N-terminus of the recombinant protein) as previously described (Groisillier et al., 2010), producing the plasmids pEsM1PDH1 and pESM1PDH1cat respectively. The integrity of sequences was verified by sequencing.

E. coli expression strains BL21 (DE3) transformed with recombinant plasmids pEsM1PDH1 and pEsM1PDH1cat were grown in one litre of autoinducing ZYP 5052 medium (Studier, 2005) with $200 \mu \mathrm{g} \mathrm{ml}^{-1}$ of ampicillin (final concentration) at $20^{\circ} \mathrm{C}$ and $200 \mathrm{rpm}$ for three days. Before large-scale purification, the presence of recombinant proteins was verified by applying a mini-purification protocol described previously by Groisillier et al. (2010). To purify the recombinant proteins, bacteria were harvested by centrifugation at $4,000 \mathrm{rpm}$ for $30 \mathrm{~min}$, then resuspended in $5 \mathrm{ml}$ of buffer $\mathrm{A}(20 \mathrm{mM}$ Tris- $\mathrm{HCl}, \mathrm{pH}$ 7.6, $200 \mathrm{mM} \mathrm{NaCl}, 10 \mathrm{mM}$ imidazole, anti-protease (Novagen, Germany), DNase I (Sigma Aldrich, USA) before lysis with a French press. The lysate was centrifuged for $1 \mathrm{~h}$ at $14,000 \mathrm{rpm}$, and the cell-free supernatant was filtered through 0.2 $\mu \mathrm{M}$ filter before loading onto a HisPrep ${ }^{\mathrm{TM}}$ FF $16 / 10$ column $(1.6 \times 10 \mathrm{~cm}$, GE Healthcare, 
USA) equilibrated in buffer $B(20 \mathrm{mM}$ Tris- $\mathrm{HCl}, \mathrm{pH}$ 7.6, $200 \mathrm{mM} \mathrm{NaCl}, 500 \mathrm{mM}$ imidazole) using the ÄKTA Avant system (GE Healthcare, USA). Proteins were eluted with a linear increasing gradient (0 to 100\%) of buffer B within 5 column volumes and fractions of $1 \mathrm{ml}$ were collected. To improve the purification of the recombinant protein, fractions containing the recombinant tagged protein were injected onto a HiLoad ${ }^{\mathrm{TM}}$ Superdex 200 column (GE Healthcare, USA) previously equilibrated with buffer C (20 $\mathrm{mM}$ Tris- $\mathrm{HCl} \mathrm{pH}$ 7.6, $200 \mathrm{mM} \mathrm{NaCl}$ ). Fractions were then eluted with the same buffer at a flow rate of $1 \mathrm{ml} \mathrm{min}^{-1}$.

After each step of purification, protein fractions were analyzed by SDS-PAGE using 12\% Criterion precast Bis-Tris gels (Bio-Rad, USA) and by Western-Blot. Transfer from gel onto ready to use $0.2 \mu \mathrm{m}$ nitrocellulose membrane was done using a TransBlot Turbo system in the condition specified by the manufacturer (Bio-Rad, USA). Monoclonal anti-polyhistidine peroxidase conjugate antibody (Sigma) that specifically recognizes the his-tagged fusion proteins was used at a final concentration of 1/10,000. In parallel, M1PDH1 activity was checked according to the protocol described in the next paragraph. Protein concentrations were determined according to Bradford (1976) using the Bio-Rad protein assay with BSA as protein standard (calibration range from 0.55 to $5.5 \mathrm{mg} \mathrm{ml}$ ). Protein concentration of pure recombinant proteins was also estimated at 280 nm using a Nanodrop 2000 Spectophotometer (Thermo Scientific, USA). A molar extinction coefficient of $37,525 \mathrm{M}^{-1} \mathrm{~cm}^{-1}$ and a molecular weight of $43 \mathrm{kDa}$, deduced from the EsM1PDH1cat protein sequence, were used to calculate the concentration of enzyme (Expasy, ProtParam tool; Gasteiger et al., 2005).

\subsection{Determination of M1PDH activity}


If not noted otherwise, M1PDH activity was assayed in a $100 \mu \mathrm{l}$ final reaction volume, in technical triplicates and at $30^{\circ} \mathrm{C}$. All chemicals used were from Sigma-Aldrich (USA). Activity was measured in both directions, i.e. F6P reduction and M1P oxidation, by monitoring changes in absorbance at $340 \mathrm{~nm}$ in a microplate Safire $^{2}$ UV spectrophotometer reader (Tecan). Reactions were initiated by adding algal protein extracts (32 to $45 \mu \mathrm{g}$ of total proteins) or purified recombinant EsM1PDH1cat (about 2 $\mu \mathrm{g})$ to standard reaction mixtures containing final concentration of $50 \mathrm{mM}$ Tris- $\mathrm{HCl}(\mathrm{pH}$ 7), $0.2 \mathrm{mM} \mathrm{NADH}$ and $1-3 \mathrm{mM}$ of F6P for the reduction activity, and of $50 \mathrm{mM}$ Tris- $\mathrm{HCl}$ $(\mathrm{pH} 9), 0.5 \mathrm{mM} \mathrm{NAD}^{+}$and $0.5 \mathrm{mM}$ of M1P for the oxidation activity. The effect of $\mathrm{pH}$ was determined over a range from 5.5 to 11 in various buffers at $50 \mathrm{mM}$ final concentration (MES, pH 5.5 to 7; Tris-acetate, $\mathrm{pH} 6$ to 7 ; Tris-HCl, $\mathrm{pH} 6.5$ to 9; Bis-Tris, $\mathrm{pH} 8.5$ to 9.5; Hepes-KOH, $\mathrm{pH} 7$ to 9; Glycine, $\mathrm{pH} 8.5$ to 10.5; CAPS, $\mathrm{pH} 9.5$ to 11). The effect of temperature was assessed between $5^{\circ} \mathrm{C}$ and $50^{\circ} \mathrm{C}$. To determine enzyme specificity, $\operatorname{NAD}(\mathrm{H})$ and $\operatorname{NADP}(\mathrm{H})$ were tested as potential co-factors, and different phosphated sugars (glucose-6P, mannose-6P, fructose-1P and glucose-1P) were assayed as putative substrates. Influence of $\mathrm{NaCl}$ was examined by testing final concentration ranging from 0 to $1 \mathrm{M}$ in the reaction mixture. Finally, kinetics parameters were determined after measurement of specific activities in presence of different concentrations of F6P (0.05 to $20 \mathrm{mM}), \mathrm{M} 1 \mathrm{P}(0.005$ to $10 \mathrm{mM}), \mathrm{NADH}(0.005$ to $5 \mathrm{mM})$ and $\mathrm{NAD}^{+}(0.005$ to $0.5 \mathrm{mM})$, and by calculations based on Lineweaver-Burk curve plotting. For both activities, one $\mu$ kat corresponded to one $\mu$ mole of co-factor reduced or oxidized per second. 


\section{Acknowledgments}

The authors thank Dr. Fanny Gaillard and Karine Cahier for mass spectrometry analyses within the METABOMER facilities, Sylvie Rousvoal and Dr. Simon M. Dittami for providing E. siliculosus diurnal samples, Marie-Pascale Prud'homme, Rémi Lemoine and Didier Flament for fruitful discussions. Patricia Bonin received a PhD grant by the Émergence-UPMC 2011 research program. This work also benefited from the support of the project IDEALG (ANR-10-BTBR-02) "Investissements d'avenir, BiotechnologiesBioresources".

\section{Figure and Table Legends}

Fig. 1. A. Changes in mannitol content and of M1PDH and M1Pase activities during one diurnal cycle in Ectocarpus sp. The figure is adapted from results presented in Gravot et al. (2010) for the mannitol content and in Groisillier et al. (2014) for the M1Pase activity. Grey background indicates samples harvested during the dark period. Data represent the mean value \pm SD of three independent algal cultures. B. Variations of EsM1PDH genes expression through one diurnal cycle. Bars in grey indicate results obtained for samples taken during the dark period. Data represent the mean value \pm SD of three independent algal cultures.

Fig. 2. Structure-based sequence alignment of the crystallized M1PDH from Shigella flexneri (Sh._flexneri) (PDB code 3H2Z) with orthologues from different organisms. The ESPript3 program (Robert and Gouet, 2014) was used to highlight the conserved amino 
acids which are shown in white letters on a red background. The consensus sequence is shown below the sequence alignment: amino acid strictly conserved in columns are noted in uppercase letters, while those conserved in more than $50 \%$ of the aligned sequences are noted as lowercase letters. The secondary structure of the Sh. flexneri protein is shown above the alignment. Alpha-helices are represented as helices and $\beta$ turns as arrows. Five conserved blocks as defined by Klimacek et al. (2003) for PSLDRs, named A to E, are represented below the conserved consensus sequence. M1PDH GenBank accession numbers are: Shigella flexneri (Sh._flexneri) KFZ96362; Bacillus subtilis subsp. subtilis str. 168 (Bac._subtilis), CAB12207; Enterococcus faecalis V583 (En._faecalis), NP_814201; E. coli (E._coli) str. K-12 substr. MG1655, NP_418057; Klebsiella pneumoniae (K._pneumoniae), AAD45386; Vibrio cholerae O395 (V._cholera), YP_001215036; Beauveria bassiana (B._bassiana), ACU32784; Alternaria alternata (A._alternata), AAQ63948; Phaeosphaeria nodorum SN15 (P._nodorum), Q0U6E8; Aspergillus fumigatus Af293 (As._fumigatus), XP_755399; Aspergillus niger (As._niger), AAL89587; Ei. tenella (Ei._tenella), O96437; EsMPDH1, D7FMJ8; EsMPDH2, D8LIO9; EsMPDH3, D7G793; Saccharina japonica (S.japonica), (Deng et al., 2012); Micromonas sp. (Micromonas_sp.), C1FJR6.

Fig. 3. Unrooted maximum likelihood phylogenetic tree of PSLDR proteins. Dotted lines separated M1PDH proteins from other PSLDR family members. Sequence accession numbers are indicated beside the name of species, except for SjM2DH since this sequence was deduced from analysis of RNA-seq data (Deng et al., 2012). 
Fig. 4. Purification (A) and estimation of molecular mass (B) of the recombinant histagged EsM1PDH1cat domain. A, proteins were purified by $\mathrm{Ni}^{2+}$ affinity chromatography, and eluted fractions were analyzed by SDS-PAGE (inset). B, proteins were resolved by gel filtration onto a Superdex 200 HiLoadTM column (inset), and the following proteins were used as standards for column calibration: carbonic anhydrase (29 kDa), albumin (66 kDa), alcohol dehydrogenase (150 kDa), $\beta$-amylase (200 kDa); Ve, elution volume; V0, void volume.

Fig. 5. Enzymatic properties of EsM1PDH1cat. A, effect of various $\mathrm{pH}$ buffers on the F6P reduction activity. $\mathrm{B}$, influence of various $\mathrm{pH}$ buffers on the M1P oxidation activity. All the buffers tested were at a final concentration of $50 \mathrm{mM}$. C, effect of various temperatures on the F6P reduction activity. The enzyme activities observed at $\mathrm{pH} 7.0$ in $\mathrm{Tris}-\mathrm{HCl}$ buffer (in $\mathrm{A}$ ), at $\mathrm{pH} 9.0$ in Bis-Tris buffer (in $\mathrm{B}$ ), and at $30^{\circ} \mathrm{C}$ (in $\mathrm{C}$ ), were considered $100 \%$, and all other values are indicated as relative percentages of these activities. Each value represents means $\pm S D$ calculated from three reaction assays for one round of protein purification.

Fig. 6. Influence of $\mathrm{NaCl}$ on the EsM1PDH1cat activity. The enzyme activities observed at $200 \mathrm{mM}$ were considered $100 \%$, and all other values are indicated as relative percentages of these activities. Each value represents means \pm SD calculated from three reaction assays for one round of protein purification.

Supplementary Fig. 1. Multiple alignment of the M1PDH N-terminal modules from EiM1PDH, EsM1PDH1, EsM1PDH2 and SjM1PDH. The ESPript3 program (Robert and 
Gouet, 2014) was used to highlight the conserved amino acids which are shown in white letters on a red background. The consensus sequence is shown below the sequence alignment: amino acid strictly conserved in the column are noted in uppercase letters, while those conserved in more than $50 \%$ of the aligned sequences are noted as lowercase letters.

Supplementary Fig. 2. Determination of kinetics parameters for EsM1PDH1cat. The Lineweaver-Burk plots for $K_{\mathrm{m}}$ and $V_{\mathrm{m}}$ calculations were obtained for M1P, F6P, NAD and NADH. For each substrate, values represent means \pm SD calculated from three reaction assays for one round of protein purification.

\section{References}

Ahmed, S., Cock, J.M., Pessia, E., Luthringer, R., Cormier, A., Robuchon, M., Sterck, L., Peters, A.F., Dittami, S.M., Corre, E., Valero, M., Aury, J.M., Roze, D., Van de Peer, Y., Bothwell, J., Marais, G.A.B., Coelho, S.M., 2014. A haploid system of sex determination in the brown alga Ectocarpus sp. Curr. Biol. 24, 1945-1957.

Aitken, A., 1996. 14-3-3 and its possible role in co-ordinating multiple signalling pathways. Trends Cell Biol. 6, 341-347.

Allocco, J.J., Profous-Juchelka, H., Myers, R.W., Nare, B., Schmatz, D.M., 1999. Biosynthesis and catabolism of mannitol is developmentally regulated in the protozoan parasite Eimeria tenella. J. Parasitol. 85, 167-173. 
Allocco, J.J., Nare, B., Myers, R.W., Feiglin, M., Schmatz, D.M., Profous-Juchelka, H., 2001. Nitrophenide (Megasul) blocks Eimeria tenella development by inhibiting the mannitol cycle enzyme mannitol-1-phosphate dehydrogenase. J. Parasitol. 87, $1441-1448$.

Altschul, S.F., Madden, T.L., Schäffer, A.A., Zhang, J.H., Zhang, Z., Miller, W., Lipman, D.J., 1997. Gapped BLAST and PSI-BLAST: a new generation of protein database search programs. Nucleic Acids Res. 25, 3389-3402.

Bellamacina, C.R., 1996. Protein motifs. 9. The nicotinamide dinucleotide binding motif: a comparison of nucleotide binding proteins. FASEB J. 10, 1257-1269.

Bhatt, S.M., Mohan, A., Srivastava, S.K., 2013. Challenges in enzymatic route of mannitol production. ISRN Biotechnol. 2013, 1-13.

Bradford, M.M., 1976. A rapid and sensitive method for the quantitation of microgram quantities of protein utilizing the principle of protein-dye binding. Anal. Biochem. 72, 248-254.

Brünker, P., Altenbuchner, J., Kulbe, K.D., Mattes, R., 1997. Cloning, nucleotide sequence and expression of a mannitol dehydrogenase gene from Pseudomonas fluorescens DSM 50106 in Escherichia coli. Biochim. Biophys. Acta 1351, 157-167.

Charrier, B., Coelho, S.M., Le Bail, A., Tonon, T., Michel, G., Potin, P., Kloareg, B., Boyen, C., Peters, A.F., Cock, J.M., 2008. Development and physiology of the brown alga Ectocarpus siliculosus: two centuries of research. New Phytol. 177, 319-332. 
Chase, T., 1986. Mannitol-1-phosphate dehydrogenase of Escherichia coli. Chemical properties and binding of substrates. Biochem. J. 239, 435-443.

Chaturvedi, V., Bartiss, A., Wong, B., 1997. Expression of bacterial $\mathrm{mtlD}$ in Saccharomyces cerevisiae results in mannitol synthesis and protects a glyceroldefective mutant from high-salt and oxidative stress. J. Bacteriol. 179, 157-162.

Cock, J.M., Sterck, L., Rouzé, P., Scornet, D., Allen, A.E., Amoutzias, G., Anthouard, V., Artiguenave, F., Aury, J.M., Badger, J.H., Beszteri, B., Billiau, K., Bonnet, E., Bothwell, J.H., Bowler, C., Boyen, C., Brownlee, C., Carrano, C.J., Charrier, B., Cho, G.Y., Coelho, S.M., Collén, J., Corre, E., Da Silva, C., Delage, L., Delaroque, N., Dittami, S.M., Doulbeau, S., Elias, M., Farnham, G., Gachon, C.M.M., Gschloessl, B., Heesch, S., Jabbari, K., Jubin, C., Kawai, H., Kimura, K., Kloareg, B., Küpper, F.C., Lang, D., Le Bail, A., Leblanc, C., Lerouge, P., Lohr, M., Lopez, P.J., Martens, C., Maumus, F., Michel, G., Miranda-Saavedra, D., Morales, J., Moreau, H., Motomura, T., Nagasato, C., Napoli, C.A., Nelson, D.R., Nyvall-Collén, P., Peters, A.F., Pommier, C., Potin, P., Poulain, J., Quesneville, H., Read, B., Rensing, S.A., Ritter, A., Rousvoal, S., Samanta, M., Samson, G., Schroeder, D.C., Ségurens, B., Strittmatter, M., Tonon, T., Tregear, J.W., Valentin, K., von Dassow, P., Yamagishi, T., Van de Peer, Y., Wincker, P., 2010. The Ectocarpus genome and the independent evolution of multicellularity in brown algae. Nature 465, 617-621.

Coelho, S.M., Godfroy, O., Arun, A., Le Corguillé, G., Peters, A.F., Cock, J.M., 2011. Genetic regulation of life cycle transitions in the brown alga Ectocarpus. Plant Signal. Behav. 6, 1858-1860. 
Davison, I.R., Pearson, G.A., 1996. Stress tolerance in intertidal seaweeds. J. Phycol. $32,197-211$.

Deng, Y., Yao, J., Wang, X., Guo, H., Duan, D., 2012. Transcriptome sequencing and comparative analysis of Saccharina japonica (Laminariales, Phaeophyceae) under blue light induction. PLOS ONE 7, e39704.

Deniaud-Bouët, E., Kervarec, N., Michel, G., Tonon, T., Kloareg, B., Hervé, C., 2014. Chemical and enzymatic fractionation of cell walls from Fucales: insights into the structure of the extracellular matrix of brown algae. Ann. Bot. 114, 1203-1216.

Dittami, S.M., Aas, H.T., Paulsen, B.S., Boyen, C., Edvardsen, B., Tonon, T., 2011a. Mannitol in six autotrophic stramenopiles and Micromonas. Plant Signal. Behav. 6, $1237-1239$.

Dittami, S.M., Gravot, A., Goulitquer, S., Rousvoal, S., Peters, A.F., Bouchereau, A., Boyen, C., Tonon, T., 2012a. Towards deciphering dynamic changes and evolutionary mechanisms involved in the adaptation to low salinities in Ectocarpus (brown algae). Plant J. 71, 366-377.

Dittami, S.M., Gravot, A., Renault, D., Goulitquer, S., Eggert, A., Bouchereau, A., Boyen, C., Tonon, T., 2011b. Integrative analysis of metabolite and transcript abundance during the short-term response to saline and oxidative stress in the brown alga Ectocarpus siliculosus. Plant. Cell Environ. 34, 629-642. 
Dittami, S.M., Proux, C., Rousvoal, S., Peters, A.F., Cock, J.M., Coppée, J.-Y., Boyen, C., Tonon, T., 2011c. Microarray estimation of genomic inter-strain variability in the genus Ectocarpus (Phaeophyceae). BMC Mol. Biol. 12, 2.

Dittami, S.M., Riisberg, I., John, U., Orr, R.J.S., Jakobsen, K.S., Edvardsen, B., 2012b. Analysis of expressed sequence tags from the marine microalga Pseudochattonella farcimen (Dictyochophyceae). Protist 163, 143-161.

Dittami, S.M., Scornet, D., Petit, J-L., Ségurens, B., Da Silva, C., Corre, E., Dondrup, M., Glatting, K-H., König, R., Sterck, L., Rouzé, P., Van de Peer, Y., Cock, J.M., Boyen, C., Tonon, T., 2009. Global expression analysis of the brown alga Ectocarpus siliculosus (Phaeophyceae) reveals large-scale reprogramming of the transcriptome in response to abiotic stress. Genome Biol. 10, R66.

Eggert, A., Raimund, S., Van Den Daele, K., Karsten, U., 2006. Biochemical characterization of mannitol metabolism in the unicellular red alga Dixoniella grisea (Rhodellophyceae). Eur. J. Phycol. 41, 405-413.

Enquist-Newman, M., Faust, A.M.E., Bravo, D.D., Santos, C.N.S., Raisner, R.M., Hanel, A., Sarvabhowman, P., Le, C., Regitsky, D.D., Cooper, S.R., Peereboom, L., Clark, A., Martinez, Y., Goldsmith, J., Cho, M.Y., Donohoue, P.D., Luo, L., Lamberson, B., Tamrakar, P., Kim, E.J., Villari, J.L., Gill, A., Tripathi, S.A, Karamchedu, P., Paredes, C.J., Rajgarhia, V., Kotlar, H.K., Bailey, R.B., Miller, D.J., Ohler, N.L., Swimmer, C., Yoshikuni, Y., 2014. Efficient ethanol production from brown macroalgae sugars by a synthetic yeast platform. Nature 505, 239-243. 
Gaspar, P., Neves, A.R., Ramos, A., Gasson, M.J., Shearman, C.A., Santos, H., 2004. Engineering Lactococcus lactis for production of mannitol: High yields from foodgrade strains deficient in lactate dehydrogenase and the mannitol transport system. Appl. Environ. Microbiol. 70, 1466-1474.

Gasteiger E, Hoogland C, Gattiker A, Duvaud S, Wilkins MR, Appel RD, Bairoch A. 2005. Protein identification and analysis tools on the ExPASy server. (In) John M. Walker (ed): The Proteomics Protocols Handbook, Humana Press 571-607.

Ghoreishi, S.M., Shahrestani, R.G., 2009. Innovative strategies for engineering mannitol production. Trends Food Sci. Technol. 20, 263-270.

Gravot, A., Dittami, S.M., Rousvoal, S., Lugan, R., Eggert, A., Collén, J., Boyen, C., Bouchereau, A., Tonon, T., 2010. Diurnal oscillations of metabolite abundances and gene analysis provide new insights into central metabolic processes of the brown alga Ectocarpus siliculosus. New Phytol. 188, 98-110.

Groisillier, A., Hervé, C., Jeudy, A., Rebuffet, E., Pluchon, P.F., Chevolot, Y., Flament, D., Geslin, C., Morgado, I.M., Power, D., Branno, M., Moreau, H., Michel, G., Boyen, C., Czjzek, M., 2010. MARINE-EXPRESS: taking advantage of high throughput cloning and expression strategies for the post-genomic analysis of marine organisms. Microb. Cell Fact. 9, 45.

Groisillier, A., Shao, Z., Michel, G., Goulitquer, S., Bonin, P., Krahulec, S., Nidetzky, B., Duan, D., Boyen, C., Tonon, T., 2014. Mannitol metabolism in brown algae involves a new phosphatase family. J. Exp. Bot. 65, 559-570. 
Hall, T.A., 1999. BioEdit: a user-friendly biological sequence alignment editor and analysis program for Windows 95/98/NT. Nucleic Acids Symposium 41, 95-98.

Heesch, S., Cho, G.Y., Peters, A.F., Le Corguillé, G., Falentin, C., Boutet, G., Coëdel, S., Jubin, C., Samson, G., Corre, E., Coelho, S.M., Cock, J.M., 2010. A sequencetagged genetic map for the brown alga Ectocarpus siliculosus provides large-scale assembly of the genome sequence. New Phytol. 188, 42-51.

Heinrich, S., Frickenhaus, S., Glöckner, G., Valentin, K., 2012. A comprehensive cDNA library of light- and temperature-stressed Saccharina latissima (Phaeophyceae). Eur. J. Phycol. 47, 83-94.

Henstra, S.A., Duurkens, R.H., Robillard, G.T., 2000. Multiple phosphorylation events regulate the activity of the mannitol transcriptional regulator MtIR of the Bacillus stearothermophilus phosphoenolpyruvate-dependent mannitol phosphotransferase system. J. Biol. Chem. 275, 7037-7044.

Ikawa, T., Watanabe, T., Nisizawa, K., 1972. Enzymes involved in the last steps of the biosynthesis of mannitol in brown algae. Plant Cell Physiol. 13, 1017-1029.

Iwamoto, K., Kawanobe, H., Ikawa, T., Shiraiwa, Y., 2003. Characterization of saltregulated mannitol-1-phosphate dehydrogenase in the red alga Caloglossa continua. Plant Physiol. 133, 893-900.

Iwamoto, K., Kawanobe, H., Shiraiwa, Y., Ikawa, T., 2001. Purification and Characterization of Mannitol-I-Phosphatase in the Red Alga Caloglossa continua (Ceramiales, Rhodophyta). Mar. Biotechnol. (NY). 3, 493-500. 
Iwamoto, K., Shiraiwa, Y., 2005. Salt-regulated mannitol metabolism in algae. Mar. Biotechnol. (NY). 7, 407-415.

Karsten, U., Barrow, K.D., Nixdorf, O., West, J.A., King, R.J., 1997. Characterization of mannitol metabolism in the mangrove red alga Caloglossa leprieurii (Montagne) J.Agardh. Planta 201, 173-178.

Kavanagh, K.L., Klimacek, M., Nidetzky, B., Wilson, D.K., 2002. Crystal structure of Pseudomonas fluorescens mannitol 2-dehydrogenase binary and ternary complexes. Specificity and catalytic mechanism. J. Biol. Chem. 277, 43433-43442.

Kavanagh, K.L., Klimacek, M., Nidetzky, B., Wilson, D.K., 2003. Crystal structure of Pseudomonas fluorescens mannitol 2-dehydrogenase: evidence for a very divergent long-chain dehydrogenase family. Chem. Biol. Interact. 143, 551-558.

Klimacek, M., Kavanagh, K.L., Wilson, D.K., Nidetzky, B., 2003. Pseudomonas fluorescens mannitol 2-dehydrogenase and the family of polyol-specific long-chain dehydrogenases/reductases: sequence-based classification and analysis of structure-function relationships. Chem. Biol. Interact. 143, 559-582.

Klimacek, M., Nidetzky, B., 2002. Examining the relative timing of hydrogen abstraction steps during $\mathrm{NAD}(+)$-dependent oxidation of secondary alcohols catalyzed by longchain D-mannitol dehydrogenase from Pseudomonas fluorescens using $\mathrm{pH}$ and kinetic isotope effects. Biochemistry 41, 10158-10165. 
Konotchick, T., Dupont, C.L., Valas, R.E., Badger, J.H., Allen A.E., 2013. Transcriptomic analysis of metabolic function in the giant kelp, Macrocystis pyrifera, across depth and season. New Phytol. 198, 398-407.

Krahulec, S., Armao, G.C., Bubner, P., Klimacek, M., Nidetzky, B., 2009. Polyol-specific long-chain dehydrogenases/reductases of mannitol metabolism in Aspergillus fumigatus: Biochemical characterization and $\mathrm{pH}$ studies of mannitol 2dehydrogenase and mannitol-1-phosphate 5-dehydrogenase. Chem. Biol. Interact. $178,274-282$.

Krahulec, S., Armao, G.C., Klimacek, M., Nidetzky, B., 2011. Enzymes of mannitol metabolism in the human pathogenic fungus Aspergillus fumigatus--kinetic properties of mannitol-1-phosphate 5-dehydrogenase and mannitol 2dehydrogenase, and their physiological implications. FEBS J. 278, 1264-1276.

Krahulec, S., Armao, G.C., Weber, H., Klimacek, M., Nidetzky, B., 2008. Characterization of recombinant Aspergillus fumigatus mannitol-1-phosphate 5dehydrogenase and its application for the stereoselective synthesis of protio and deuterio forms of D-mannitol 1-phosphate. Carbohydr. Res. 343, 1414-1423.

Le Bail, A., Dittami, S.M., de Franco, P-O., Rousvoal, S., Cock, M.J., Tonon, T., Charrier, B., 2008. Normalisation genes for expression analyses in the brown alga model Ectocarpus siliculosus. BMC Mol. Biol. 9, 75.

McCauley, L.A.R., Wehr, J.D., 2007. Taxonomic reappraisal of the freshwater brown algae Bodanella, Ectocarpus, Heribaudiella, and Pleurocladia (Phaeophyceae) on 
the basis of rbcL sequences and morphological characters. Phycologia 46, 429439.

Mehta, R.J., Fare, L.R., Shearer, M.E., Nash, C.H., 1977. Mannitol oxidation in two Micromonospora isolates and in representative species of other actinomycetes. Appl. Environ. Microbiol. 33, 1013-1015.

Meslet-Cladière, L., Delage, L., Leroux, C.J-J., Goulitquer, S., Leblanc, C., Creis, E., Gall, E.A., Stiger-Pouvreau, V., Czjzek, M., Potin, P., 2013. Structure/function analysis of a type III polyketide synthase in the brown alga Ectocarpus siliculosus reveals a biochemical pathway in phlorotannin monomer biosynthesis. Plant Cell 25, 3089-3103.

Michel, G., Tonon, T., Scornet, D., Cock, J.M., Kloareg, B., 2010a. The cell wall polysaccharide metabolism of the brown alga Ectocarpus siliculosus. Insights into the evolution of extracellular matrix polysaccharides in Eukaryotes. New Phytol. 188, 82-97.

Michel, G., Tonon, T., Scornet, D., Cock, J.M., Kloareg, B., 2010b. Central and storage carbon metabolism of the brown alga Ectocarpus siliculosus: insights into the origin and evolution of storage carbohydrates in Eukaryotes. New Phytol. 188, 67-81.

Novotny, M.J., Reizer, J., Esch, F., Saier, M.H., 1984. Purification and properties of Dmannitol-1-phosphate dehydrogenase and D-glucitol-6-phosphate dehydrogenase from Escherichia coli. J. Bacteriol. 159, 986-990. 
Pearson, G.A., Hoarau, G., Lago-Leston, A., Coyer, J.A., Kube, M., Reinhardt, R., Henckel, K., Serrão, E.T.A., Corre, E., Olsen, J.L., 2010. An expressed sequence tag analysis of the intertidal brown seaweeds Fucus serratus (L.) and F. vesiculosus (L.) (Heterokontophyta, Phaeophyceae) in response to abiotic stressors. Mar. Biotechnol. 12, 195-213.

Persson, B., Krook, M., Jörnvall, H., 1991. Characteristics of short-chain alcohol dehydrogenases and related enzymes. Eur. J. Biochem. 200, 537-543.

Peters, A.F., Mann, A.D., Córdova, C.A, Brodie, J., Correa, J.A, Schroeder, D.C., Cock, J.M., 2010. Genetic diversity of Ectocarpus (Ectocarpales, Phaeophyceae) in Peru and northern Chile, the area of origin of the genome-sequenced strain. New Phytol. $188,30-41$.

Peters, A.F., Marie, D., Scornet, D., Kloareg, B., Cock, J.M., 2004. Proposal of Ectocarpus Siliculosus (Ectocarpales, Phaeophyceae) as a model organism for brown algal genetics and genomics. J. Phycol. 40, 1079-1088.

Pichersky, E., Lewinsohn, E., 2011. Convegent evolution in plant specialized metabolism. Ann. Rev. Plant Biol. 62, 549-566.

Prigent, S., Collet, G., Dittami, S.M., Delage, L., de Corny, F.E., Dameron, O., Eveillard, D., Thiele, S., Cambefort, J., Boyen, C., Siegel, A., and Tonon, T. 2014. The genome-scale metabolic network of Ectocarpus siliculosus (EctoGEM): a resource to study brown algal physiology and beyond. Plant J. 80, 367-381. 
Reed, R.H., Davison, I.R., Chudek, J.A., Foster, R., 1985. The osmotic role of mannitol in the Phaeophyta: an appraisal. Phycologia 24, 35-47.

Richter, D.F.E., Kirst, G.O., 1987. D-mannitol dehydrogenase and D-mannitol-1phosphate dehydrogenase in Platymonas subcordiformis: some characteristics and their role in osmotic adaptation. Planta 170, 528-534.

Riveros-Rosas, H., Julián-Sánchez, A., Villalobos-Molina, R., Pardo, J.P., Piña, E., 2003. Diversity, taxonomy and evolution of medium-chain dehydrogenase/reductase superfamily. Eur. J. Biochem. 270, 3309-3334.

Roeder, V., Collen, J., Rousvoal, S., Corre, E., Leblanc, C., Boyen, C., 2005. Identification of stress gene transcripts in Laminaria digitata (Phaeophyceae) protoplast cultures by expressed sequence tag analysis. J. Phycol. 41, 1227-1235.

Rousvoal, S., Groisillier, A., Dittami, S.M., Michel, G., Boyen, C., Tonon, T., 2011. Mannitol-1-phosphate dehydrogenase activity in Ectocarpus siliculosus, a key role for mannitol synthesis in brown algae. Planta 233, 261-273.

Saha, B.C., Racine, F.M., 2011. Biotechnological production of mannitol and its applications. Appl. Microbiol. Biotechnol. 89, 879-891.

Sand, M., Mingote, A.I., Santos, H., Müller, V., Averhoff, B., 2013. Mannitol, a compatible solute synthesized by Acinetobacter baylyi in a two-step pathway including a salt-induced and salt-dependent mannitol-1-phosphate dehydrogenase. Environ. Microbiol. 15, 2187-2197. 
Sand, M., Rodrigues, M., González, J.M., de Crécy-Lagard, V., Santos, H., Müller, V., Averhoff, B., 2014. Mannitol-1-phosphate dehydrogenases/phosphatases: A family of novel bifunctional enzymes for bacterial adaptation to osmotic stress. Environ. Microbiol. doi:10.1111/1462-2920.12503.

Schmatz, D.M. 1997. The mannitol cycle in Eimeria. Parasitology 114, S81-S89.

Schmatz, D.M., Baginsky, W.F., Turner, M.J., 1989. Evidence for and characterization of a mannitol cycle in Eimeria tenella. Mol. Biochem. Parasitol. 32, 263-270.

Shao, Z., Zhang, P., Li, Q., Wang, X., Duan, D., 2014. Characterization of mannitol-2dehydrogenase in Saccharina japonica: Evidence for a new polyol-specific longchain dehydrogenases/reductase. PLOS ONE 9, e97935.

Solomon, P.S., Waters, O.D.C., Oliver, R.P., 2007. Decoding the mannitol enigma in filamentous fungi. Trends Microbiol. 15, 257-262.

Stiller, J.W., Schreiber, J., Yue, J., Guo, H., Ding, Q., Huang, J., 2014. The evolution of photosynthesis in chromist algae through serial endosymbioses. Nat. Commun. 5, 5764.

Stoop, J.M.H., Williamson, J.D., Pharr, D.M., 1996. Mannitol metabolism in plants: a method for coping with stress. Trends Plant Sci. 1, 139-144.

Studier, F.W., 2005. Protein production by auto-induction in high density shaking cultures. Protein Expr. Purif. 41, 207-234. 
Suvarna, K., Bartiss, A., Wong, B., 2000. Mannitol-1-phosphate dehydrogenase from Cryptococcus neoformans is a zinc-containing long-chain alcohol/polyol dehydrogenase. Microbiology 146, 2705-2713.

Tamura, K., Peterson, D., Peterson, N., Stecher, G., Nei, M., Kumar, S., 2011. MEGA5: molecular evolutionary genetics analysis using maximum likelihood, evolutionary distance, and maximum parsimony methods. Mol. Biol. Evol. 28, 2731-2739.

Tenhaken, R., Voglas, E., Cock, J.M., Neu, V., Huber, C.G., 2011. Characterization of GDP-mannose dehydrogenase from the brown alga Ectocarpus siliculosus providing the precursor for the alginate polymer. J. Biol. Chem. 286, 16707-16715.

Thompson, J.D., Higgins, D.G., Gibson, T.J., 1994. CLUSTAL W: improving the sensitivity of progressive multiple sequence alignment through sequence weighting, position-specific gap penalties and weight matrix choice. Nucleic Acids Res. 22, 4673-4680.

Van Hal, J.W., Huijgen, W.J.J., López-Contreras, A.M., 2014. Opportunities and challenges for seaweed in the biobased economy. Trends Biotechnol. 32, 231-233.

Walker, J.M. (Ed.), 2005. The Proteomics Protocols Handbook. Humana Press, Totowa, NJ.

Wargacki, A.J., Leonard, E., Win, M.N., Regitsky, D.D., Santos, C.N.S., Kim, P.B., Cooper, S.R., Raisner, R.M., Herman, A., Sivitz, A.B., Lakshmanaswamy, A., Kashiyama, Y., Baker, D., Yoshikuni, Y., 2012. An engineered microbial platform for direct biofuel production from brown macroalgae. Science 335, 308-313. 
Watanabe, S., Hamano, M., Kakeshita, H., Bunai, K., Tojo, S., Yamaguchi, H., Fujita, Y., Wong, S.L., Yamane, K., 2003. Mannitol-1-phosphate dehydrogenase (MtID) is required for mannitol and glucitol assimilation in Bacillus subtilis: Possible cooperation of mtl and gut operons. J. Bacteriol. 185, 4816-4824.

Wei, N., Quarterman, J., Jin, Y.-S., 2013. Marine macroalgae: an untapped resource for producing fuels and chemicals. Trends Biotechnol. 31, 70-77.

Wisselink, H.W., Weusthuis, R.A., Eggink, G., Hugenholtz, J., Grobben, G.J., 2002. Mannitol production by lactic acid bacteria: a review. Int. Dairy J. 12, 151-161.

Wisselink, H.W., Moers, A.P.H.A., Mars, A.E., Hoefnagel, M.H.N., de Vos, W.M., Hugenholtz, J., 2005. Overproduction of heterologous mannitol 1-phosphatase: a key factor for engineering mannitol production by Lactococcus lactis. Appl. Environ. Microbiol. 71, 1507-1514.

Wong, T.K-M., Ho, C-L., Lee, W-W., Rahim, R.A., Phang, S-M., 2007. Analyses of expressed sequence tags from Sargassum binderi (phaeophyta). J. Phycol. 43, $528-534$.

Yamaguchi, T., Ikawa, T., Nisizawa, K., 1969. Pathway of mannitol formation during photosynthesis in brown algae. Plant Cell Physiol. 10, 425-440.

Ye, R.-X., Yu, Z., Shi, W.-W., Gao, H.-J., Bi, Y.-H., Zhou, Z.-G., 2013. Characterization of $\alpha$-type carbonic anhydrase (CA) gene and subcellular localization of $\alpha-C A$ in the gametophytes of Saccharina japonica. J. Appl. Phycol. 26, 881-890. 
Table1. Comparison of the biochemical properties of M1PDHs from different organisms.

\begin{tabular}{|c|c|c|c|c|c|c|c|c|c|c|c|c|}
\hline & & \multicolumn{6}{|c|}{ Specific activity } & \multirow[b]{2}{*}{ PM subunit } & \multirow{2}{*}{\multicolumn{2}{|c|}{ pH optimum }} & \multirow{3}{*}{$\begin{array}{l}\text { Temp optimum } \\
\left({ }^{\circ} \mathrm{C}\right)\end{array}$} & \multirow{3}{*}{ Reference } \\
\hline & & \multicolumn{2}{|c|}{ ( $\mu \mathrm{kat} / \mathrm{mg})$} & \multicolumn{4}{|c|}{$K_{\mathrm{m}}(\mathrm{mM})$} & & & & & \\
\hline & & F6P & M1P & F6P & M1P & $\mathrm{NADH}$ & $\operatorname{NAD}^{+}$ & (kDa) & Reduction & dation & & \\
\hline \multirow[t]{3}{*}{ Bacteria } & E. coli & 11.90 & & & 0.80 & & 0.20 & 40 (monomer) & 7,0 & 9,0 & & Novotny et al. 1984 \\
\hline & V. cholera & 2.10 & & 1.54 & & & & 42 (monomer) & 7.5 & & 37 & Rambhatla et al. 2011 \\
\hline & Acinetobacter sp. & 2.16 & & 13.60 & & & & 81 & & & 30 & Sand et al. 2013 \\
\hline \multirow[t]{4}{*}{ Fungi } & B. bassiana & 11.20 & & 0.90 & & & & 42 & 7,0 & & 30 & Wang et al. 2010 \\
\hline & As. fumigatus & 2.80 & 0.29 & 2.10 & 0.23 & 0.016 & 0.75 & 40 (monomer) & 7.1 & & 25 & Krahulec et al. 2008 \\
\hline & As. niger & 2.50 & & 0.54 & 0.038 & 0.005 & 0.083 & 40 & 7.5 & 9.5 & & Kiser et al. 1981 \\
\hline & C. neoformans & & 1.93 & 0.30 & 0.055 & 0.099 & 0.11 & 36 (homotetramer) & 7,0 & 9,0 & & Survarna et al. 2000 \\
\hline Apicomplexa & Ei. tenella & & & 0.20 & & & & 67 & 7.5 & 7.5 & 41 & Schmatz et al. 1989 \\
\hline \multirow[t]{6}{*}{ Alga } & Sp. pacificum & 0.0077 & 0.00125 & 0.28 & 0.25 & 0.013 & 0.071 & & 6.5 & 10.0 & & Ikawa et al. 1972 \\
\hline & P. subcordiformis & & & 5.50 & & & & & 7.5 & & & Richter and Kirst. 1987 \\
\hline & D. grisea & & & 1.18 & 0.61 & & & & & & & Eggert et al. 2006 \\
\hline & C. leprieurii & & $\mathrm{p}$ & 1.40 & 0.09 & 0.02 & 0.023 & & 7.0 & 8.5 & & Karsten et al. 1997 \\
\hline & C. continua & 3.80 & & 0.15 & 0.051 & 0.003 & 0.026 & 53 (monomer) & 7.2 & 9.0 & & Iwamoto et al. 2003 \\
\hline & Ectocarpus sp. & 0.77 & 0.26 & 0.19 & 0.38 & 0.16 & 0.022 & 42 (monomer) & 7.0 & 9.0 & 30 & This study \\
\hline
\end{tabular}


A

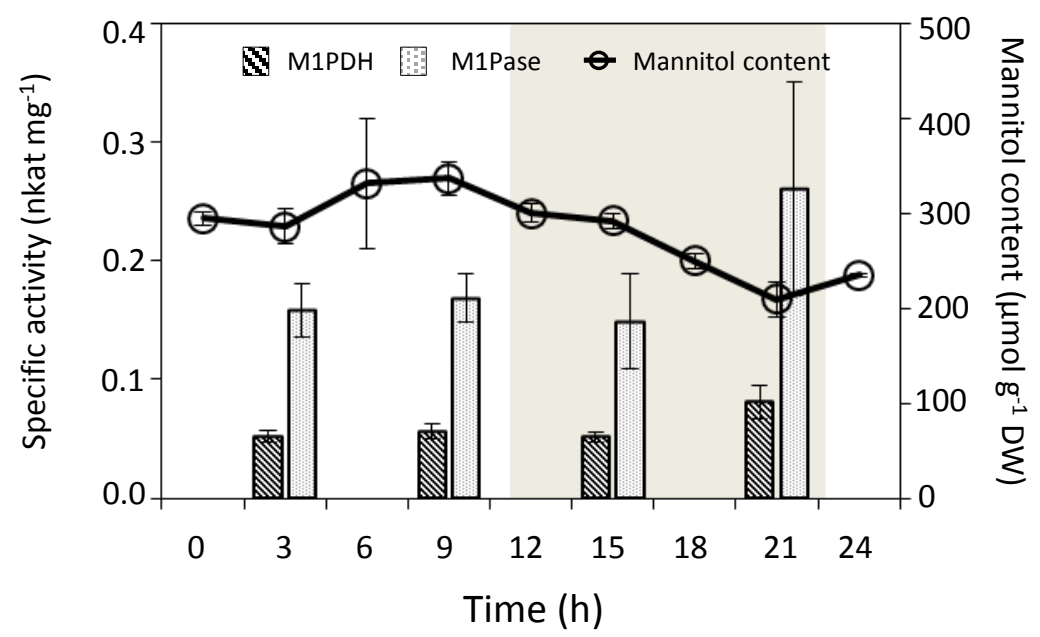

B
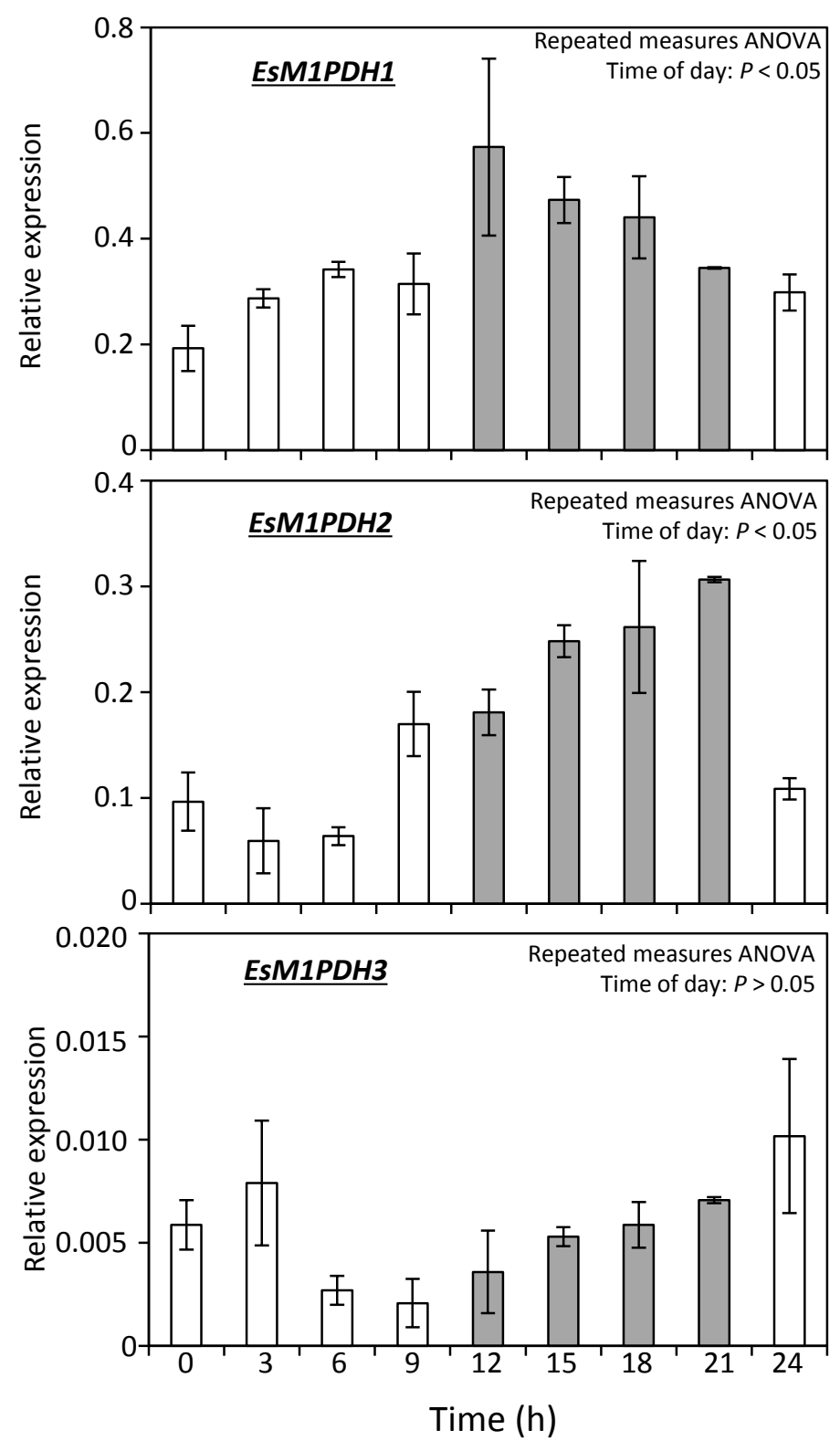

Fig. 1 

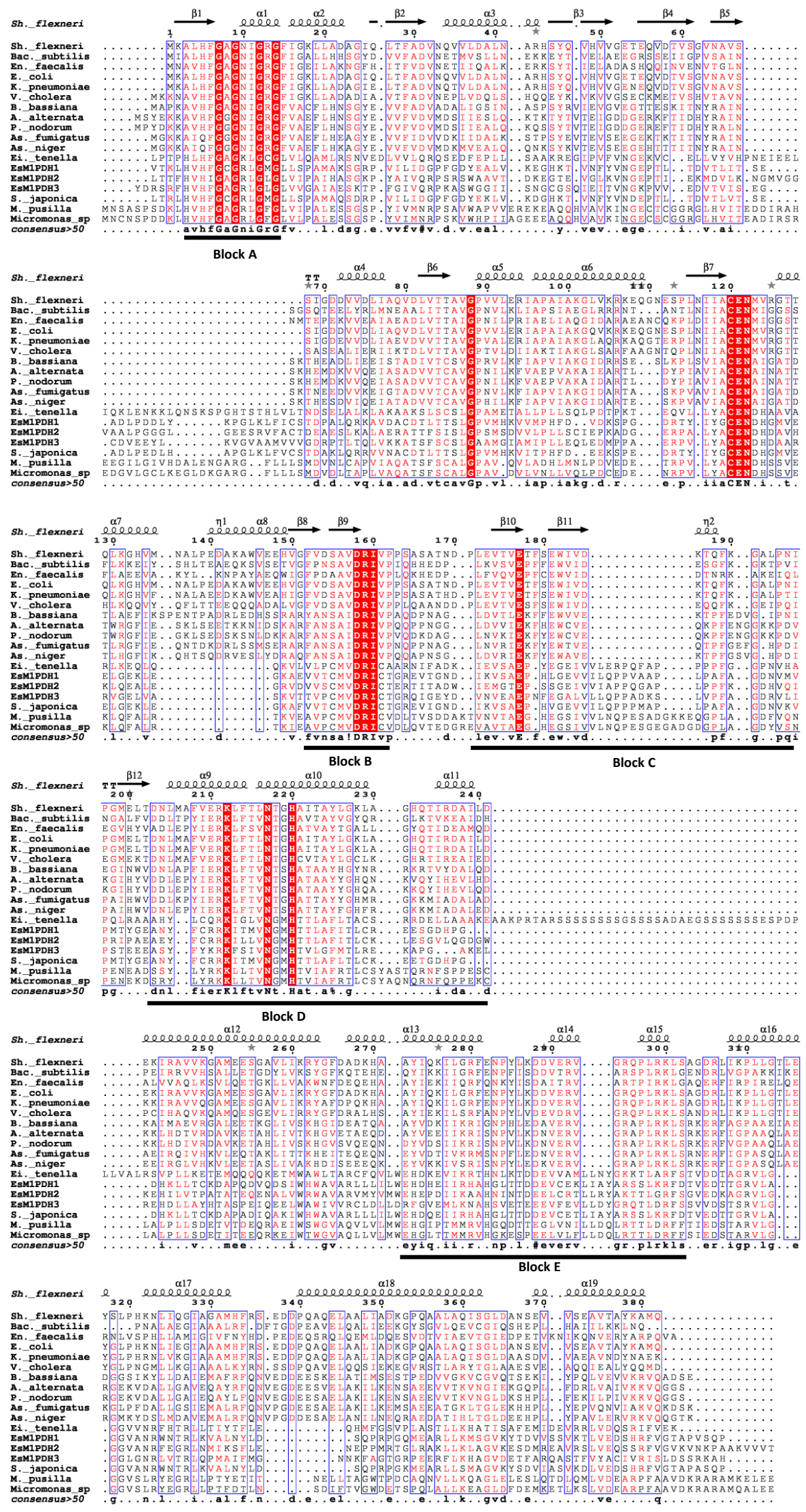


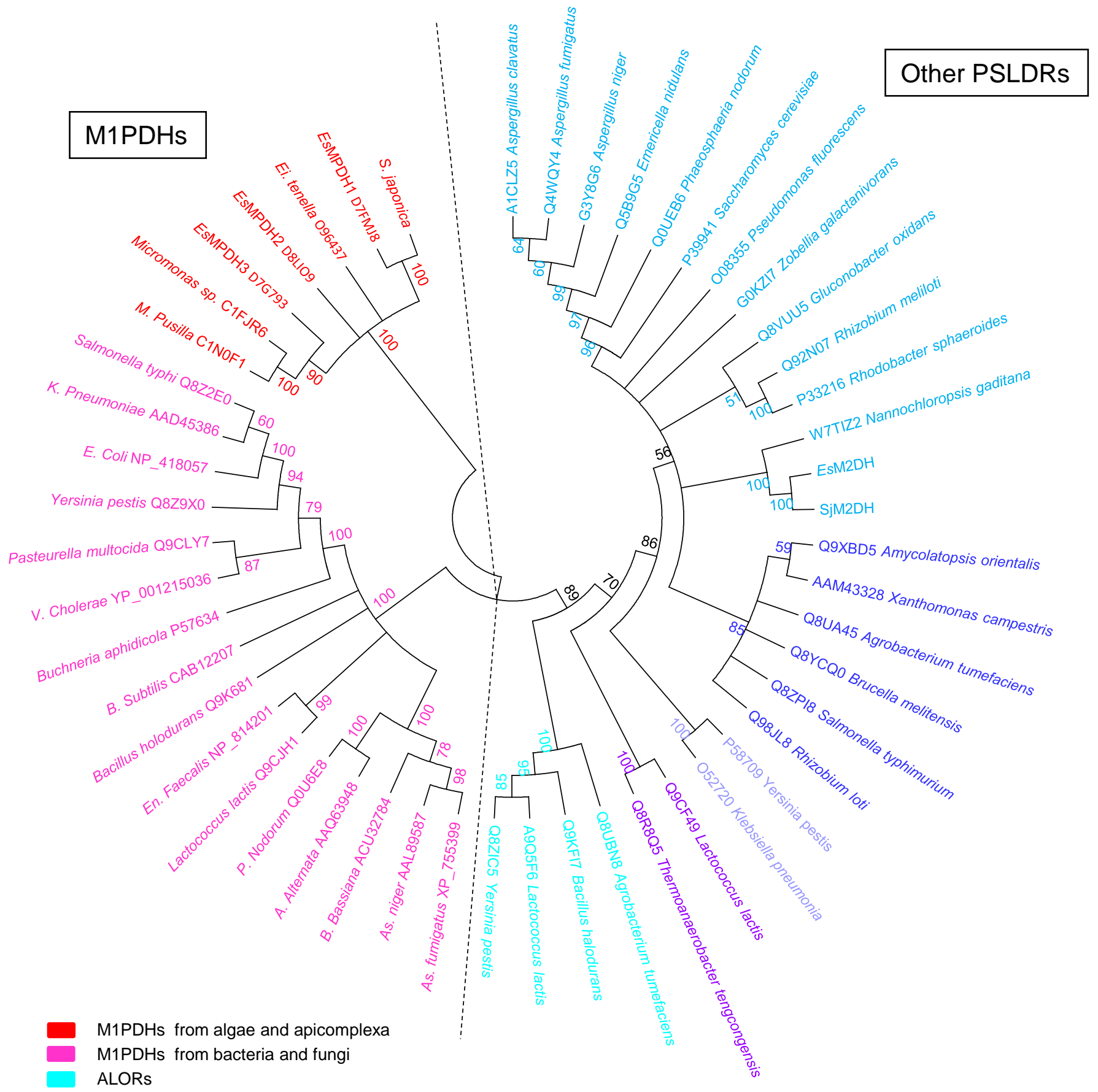

FURs

DALDs

MAORs

M2DHs

Fig. 3 

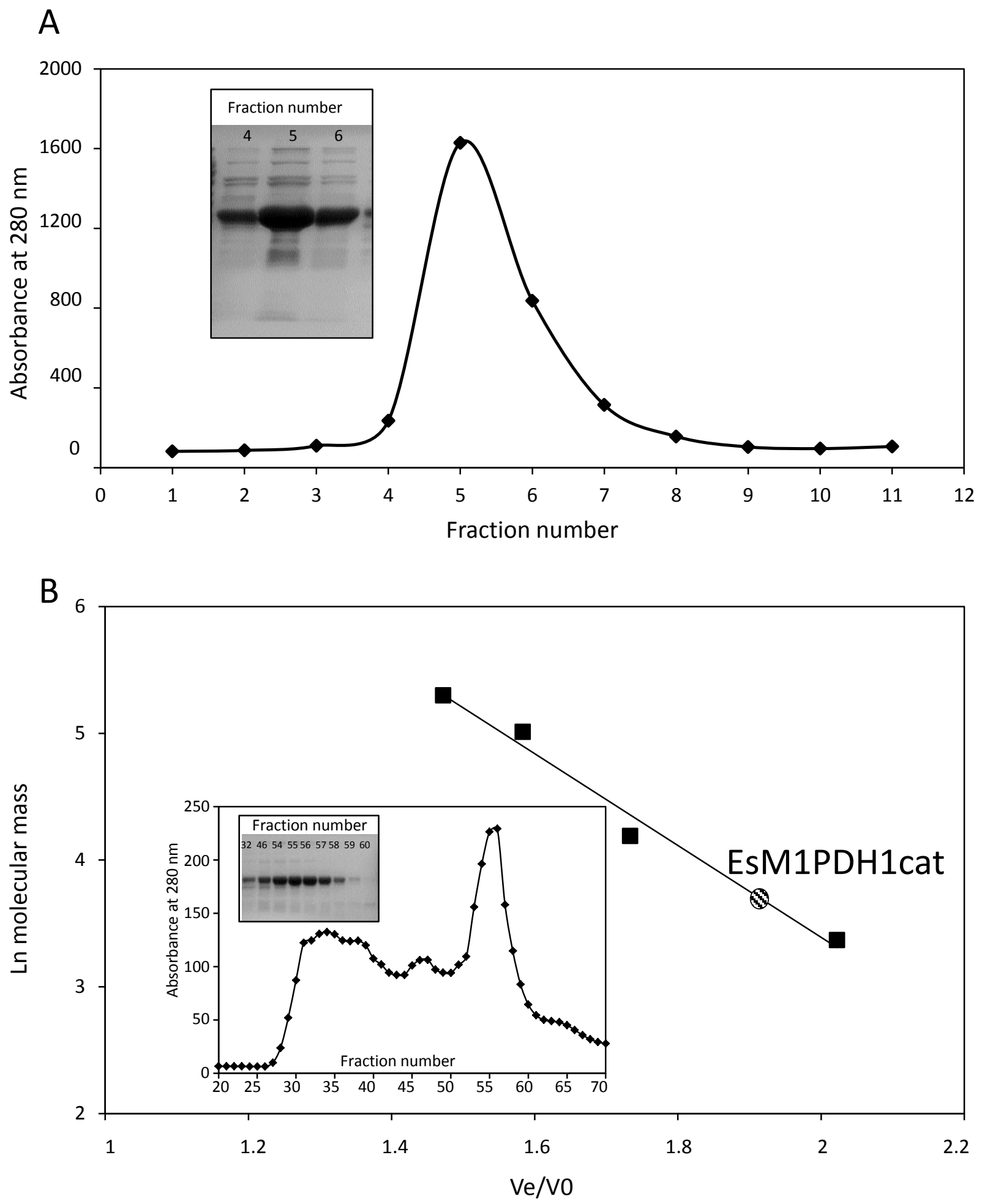

Fig. 4 

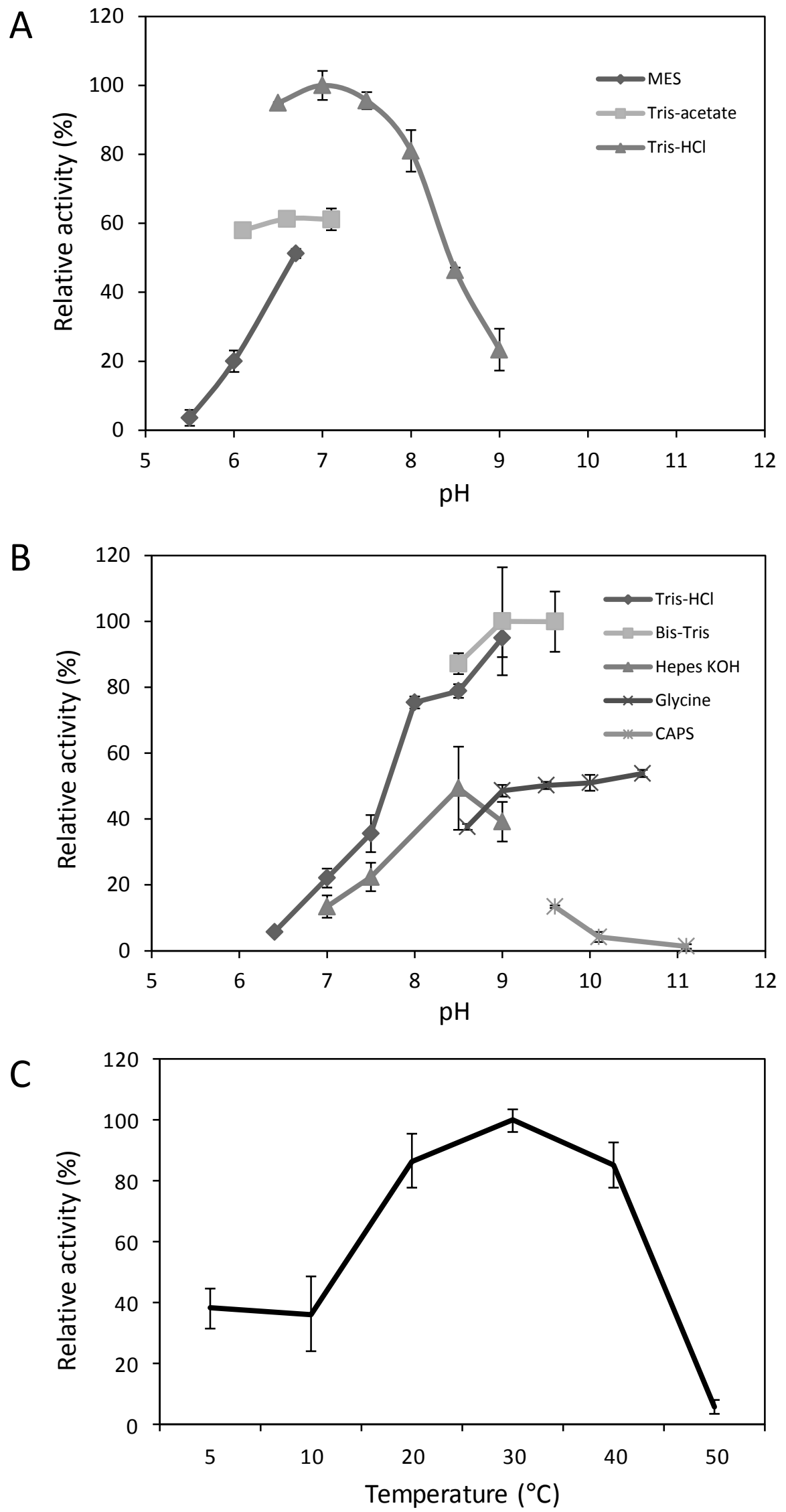

Fig. 5 

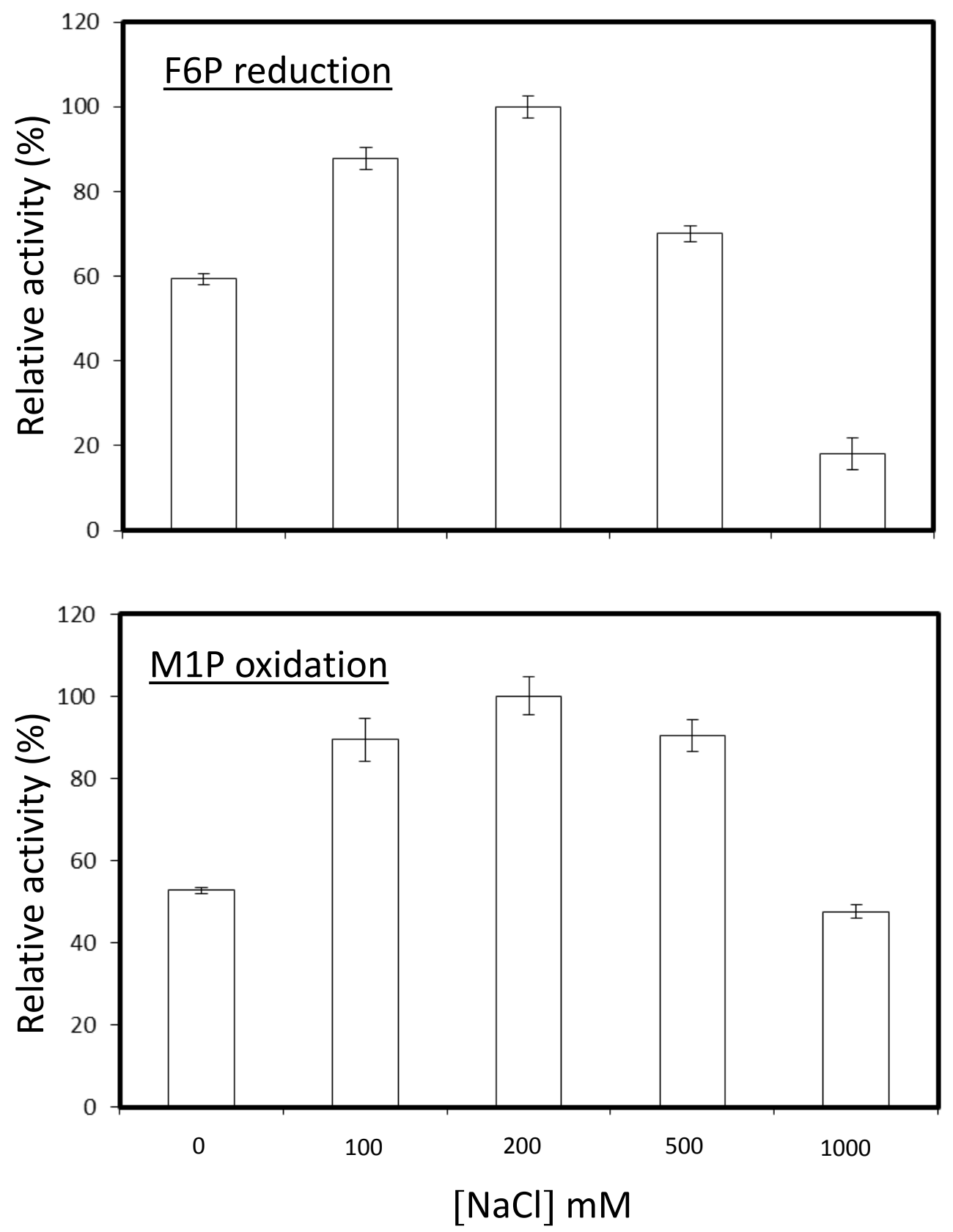

Fig. 6 
1 10

20

30

40

50

60

MAAP GCEAPA DHEA IH LARPVFE VLDH PAILRFRKDYQLHRLGYAKGAKGEVGAALRKVAEKQQQQQQG

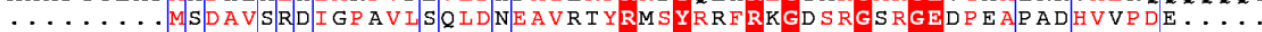

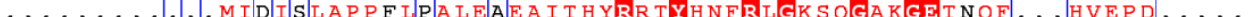

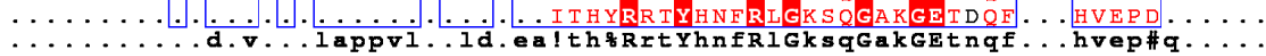

ESMPDH1

S. japonica

consensus $>50$

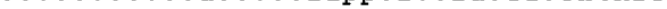

Ei.tenella

ESMPDH2

EsMPDH1

s. japonica

consensus $>50$
(20)

100

110

120

130

140

作

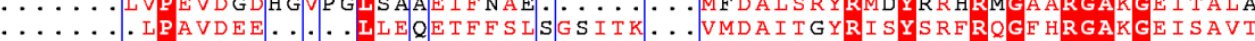
$\ldots . . .$. MPAMDEG ... LLEEETF S IAGPMTK...VMDA I TAYRI SYSRFROGFHRGAKGE I SAVT ..... . llpevded... . Lleqetffa..gp.tk. . vmdaitryRisYsrfRqGfaRGAkGeisavt

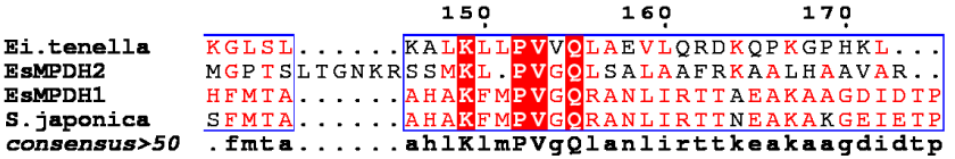

Supplementary fig. 1 

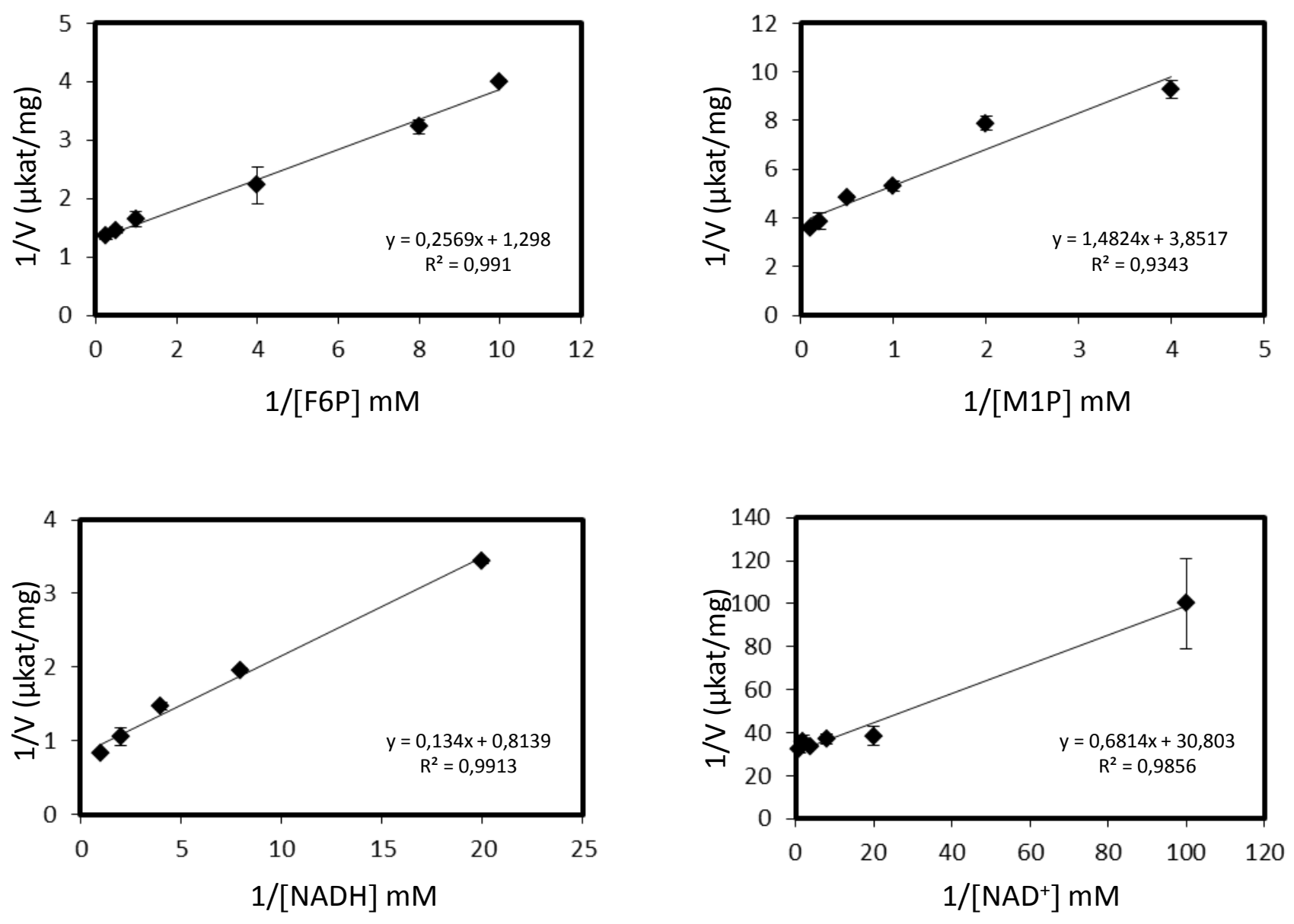

Supplementary fig. 2 